\title{
MerCadoteCnia ESTRATÉGICA: teoría e impacto en las unidades de información
}

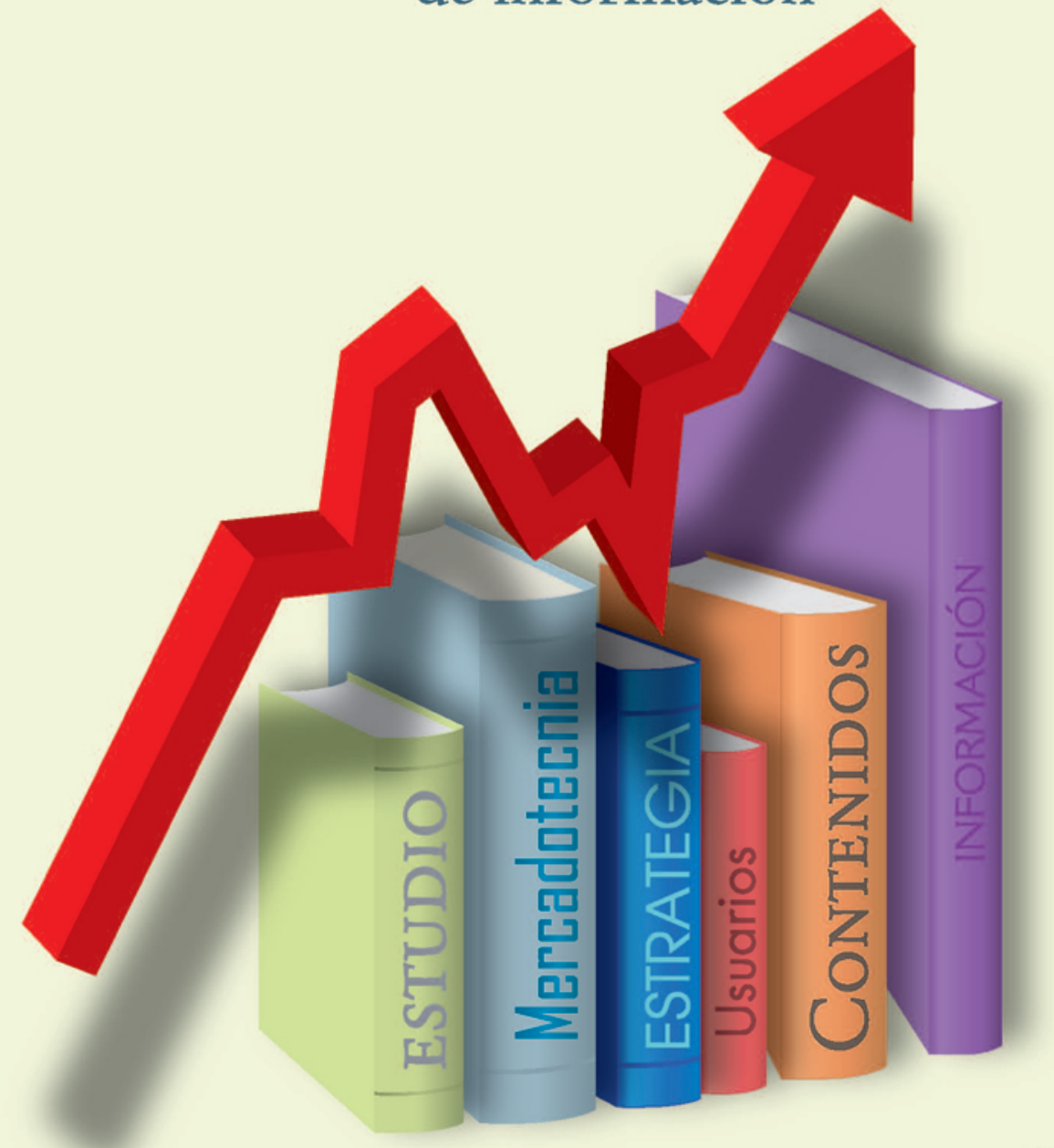

Coordinador Fernando Edmundo González Moreno 


\section{La presente obra está bajo una licencia de:}

\section{http://creativecommons.org/licenses/by-nc-sa/3.0/deed.es MX}

\section{Atribución-No Comercial-Licenciamiento Reciproco 3.0 Unported}

Eres libre de:

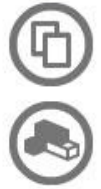

copiar, distribuir y comunicar públicamente la obra

hacer obras derivadas

Bajo las condiciones siguientes:

Atribución - Debes reconocer la autoría de la obra en los términos

especificados por el propio autor o licenciante.

No comercial - No puedes utilizar esta obra para fines comerciales.

Licenciamiento Recíproco - Si alteras, transformas o creas una obra a

partir de esta obra, solo podrás distribuir la obra resultante bajo una licencia

igual a ésta.

\section{Esto es un resumen fácilmente legible del: texto legal (de la licencia completa)}

En los casos que sea usada la presente obra, deben respetarse los términos especificados en esta licencia.
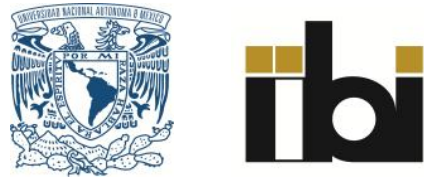
Mercadotecnia estratégica: teoría e impacto en las unidades de información 
COLECCIÓN

Apoyo a la Enseñanza Bibliotecológica

Instituto de Investigaciones Bibliotecológicas y de la Información 


\title{
Mercadotecnia estratégica: teoría e impacto en las unidades de información
}

\author{
Coordinador \\ Fernando Edmundo González Moreno
}

Universidad Nacional Autónoma de México

2014 
Z699.5 Mercadotecnia estratégica : teoría e impacto en las unidades de M34M47 información / coordinador Fernando Edmundo González Moreno. -- México : UNAM, Instituto de Investigaciones Bibliotecológicas y de la Información, 2014.

ix, 105 p. -- ( Apoyo a la enseñanza bibliotecológica) ISBN: 978-607-02-5740-7

1. Mercadotecnia -- Unidades de Información 2 Mercadotecnia -- Servicios de Información 3. Mercadotecnia -- Redes Sociales en Internet I. González Moreno, Fernando Edmundo, coordinador II. ser.

Diseño de portada: SPAFA

Primera Edición 2014

DR C Universidad Nacional Autónoma de México

Ciudad Universitaria, 04510, México D.F.

Impreso y hecho en México

ISBN: 978-607-02-5740-7 


\section{Tabla de contenido}

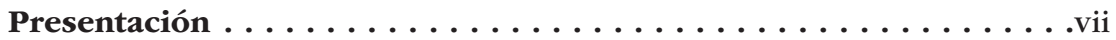

César Augusto Ramírez Velázquez

MARKETING ORIENTADO A LAS UNIDADES DE INFORMACIÓN . . . . . . . . . 1 Fernando Edmundo González Moreno

EL COMPORTAMIENTO DEL USUARIO COMO CONSUMIDOR DE INFORMACIÓN . . . . . . . . . . . . . . . . . . . . . 27 Fernando Edmundo González Moreno

INVESTIGACIÓN DE MERCADOS EN LAS UNIDADES DE INFOR-

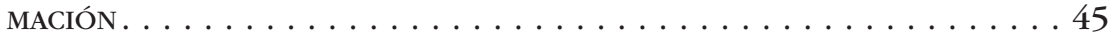
Carlos Curiel Rivera

LAS REDES SOCIALES Y LAS UNIDADES DE INFORMACIÓN . . . . . . . . . . . 67 Javier Velázquez García 


\section{Presentación}

6 Todas las instituciones tienen que comunicar su derecho a existir". Con esta provocativa frase, Wolfgang

1 Ratzek, de la Stuttgart Media University, fundamenta la lucha permanente que mantienen las bibliotecas en todo el mundo por hacerse visibles y, así, garantizar su continuidad.

De acuerdo con un estudio de la American Library Association titulado Public Library Funding and Technology Access Study, 2010-11, las bibliotecas públicas en Estados Unidos han enfrentado severos recortes presupuestales durante los últimos años ( $40 \%$ en $2009 ; 56 \%$ en $2010 ; 60 \%$ en 2011, y 65\% en 2012).

Esto recortes son producto de las sucesivas crisis económicas que se han presentado en todo el mundo, y afectan por igual a las bibliotecas públicas, escolares, académicas y especializadas. Desafortunadamente, este panorama económico no va a cambiar en el futuro, por lo que los bibliotecarios tendrán que aprender a vivir y prosperar en entornos recesivos. 
Para las bibliotecas y unidades de información, es fundamental difundir sus valores y servicios. Por ello, es muy importante colocar en el debate público el valor de los servicios bibliotecarios, así como advertir los beneficios que representa para la sociedad contar con bibliotecas robustas y vivas.

Las bibliotecas han sido entidades de servicio por excelencia, y éste es precisamente uno de los componentes más importantes en la cadena del proceso de marketing. Identificar al usuario como un cliente y consumidor de información, definir el mercado al que se atiende, así como elaborar planes estratégicos, constituyen aspectos estrechamente ligados a esa disciplina.

La Federación Internacional de Asociaciones e Instituciones Bibliotecarias (IFLA) define el marketing como el proceso de planeación y desarrollo de conceptos e ideas que permiten la promoción de bienes y servicios para favorecer procesos de intercambio que satisfagan objetivos individuales y organizacionales.

En este sentido, una parte fundamental del quehacer bibliotecario es la creación, comunicación y entrega de servicios informativos con valor para que, como consecuencia, se puedan gestionar relaciones de largo plazo con los usuarios de las bibliotecas que impacten positivamente a la sociedad en su conjunto. La llegada de nuevas formas de comunicación y trasmisión de conocimientos (Internet, redes sociales, etcétera) obligan a las bibliotecas a rehacer los puentes y estrechar la relación entre información y usuario.

El desarrollo de la mercadotecnia aplicada al ámbito bibliotecario en nuestro país es un área que ha venido desarrollándose desde hace unos pocos años; poco a poco, se ha ido trasmitiendo, principalmente desde los ámbitos universitarios, a través de cursos y congresos, así como por me- 
dio de experiencias exitosas que impactan en la comunidad bibliotecaria. Por lo tanto, es objetivo del presente trabajo tratar de contribuir, con "un grano de arena", a llenar el vació que existe en cuanto a literatura sobre el tema.

Los autores de esta obra presentan en forma didáctica los conceptos teóricos y las aplicaciones prácticas que permitirán iniciar proyectos locales de marketing bibliotecario. Desde la conceptualización del marketing hasta las potencialidades que nos ofrecen las redes sociales, los cuatro capítulos de este libro llevan al lector, paso a paso, hacia el conocimiento y aplicación del marketing social.

Este libro busca, también, despertar en los estudiantes de bibliotecología actitudes abiertas hacia la administración, ya que en el futuro enfrentarán una lucha cada vez más áspera por obtener, preservar e incrementar los recursos económicos para sus organizaciones. El éxito de esta misión estará determinado por la habilidad de cada cual para evaluar, mejorar y promocionar los productos y servicios que se ofrecen.

Para los profesionistas en activo resultará muy interesante el contenido del volumen, ya que les facilitará la asimilación de los conceptos expuestos y enriquecerá su desarrollo profesional.

César Augusto Ramírez Velázquez 
Marketing orientado a las unidades de información

\author{
FERNANDO EDMUNDO GONZÁLEZ MORENO \\ Universidad de las Américas A.C. \\ Biblioteca
}

\title{
INTRODUCCIÓN
}

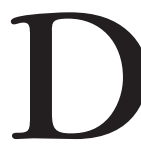

e acuerdo con Philip Kotler (2004), la mercadotecnia es una actividad humana dirigida a satisfacer necesidades, carencias y deseos a través de procesos de intercambio.

Como disciplina administrativa, sus inicios se remontan a principios del siglo pasado; sin embargo, existe desde que los seres humanos comenzaron a integrarse en pequeñas comunidades donde las actividades de subsistencia se basaban en la recolección y la caza, lo cual requería del intercambio de productos para que los pueblos comenzaran a cubrir sus necesidades básicas. De esta manera, con el trueque al principio y después con la adopción de medios comunes de pago, el intercambio de productos y mercancías sentó las bases del comercio como una de las actividades preponderantes del ser humano.

En este sentido, Valenzuela (2006) señala que la mercadotecnia no es una actividad reciente, ya que abarca tareas 
que siempre han existido y que se basan en un sistema de intercambio.

La perfección de sus habilidades manuales llevó al hombre a elaborar utensilios cada vez más sofisticados, los cuales a su vez le permitieron alcanzar mayores grados de desarrollo en la vida. Este crecimiento en los niveles de bienestar estuvo asociado al concepto primario de calidad: a mayor nivel de habilidad para desempeñar una tarea, mayor nivel de bienestar.

Una muestra de lo descrito se encuentra en el caso de los egipcios, quienes hicieron gala de destreza y habilidad al construir sus pirámides, ya que tan colosales proyectos sólo pudieron ser llevados a cabo a través de complejos procesos organizativos que tenían como objetivo cubrir los deseos y necesidades manifiestas de los faraones. Desde el diseño de los monumentos hasta la orientación que tendrían las edificaciones, alineadas con el Cinturón de Orión, pasando por la dirección de los más de 25 mil esclavos que trabajaron simultáneamente a lo largo de 23 años, se identifican factores que pretendían satisfacer un deseo de posteridad.

Otro ejemplo de la intencionalidad por cumplir con las expectativas de los clientes se encuentra en el Código de Hammurabi (2,150 a. C.) que, en su regla 229, señala que "si un constructor hace una casa y no la hace con buena resistencia y la casa se derrumba y mata a los ocupantes, el constructor debe ser ejecutado". Si bien la sanción resultaba una consecuencia drástica, queda claro que en esa época sólo se podía engañar una vez al consumidor.

Posteriormente, durante la Edad Media, los artesanos más hábiles ya solían colocar una marca en sus productos, garantizando así no sólo la calidad de la materia prima sino también el proceso de manufactura, lo cual evidentemente repercutía en los niveles de satisfacción de los compradores; 
esto es, a mayor nivel de calidad mayor satisfacción. Podría decirse que con ello inicia el reconocimiento de las marcas.

Durante el período comprendido entre el siglo XVIII y principios del XIX, se desarrolló la denominada Revolución Industrial, la cual se basaba en el empleo intensivo del vapor, y posteriormente del gas y la electricidad, con fines de industrialización.

En esta etapa, la elaboración de productos en forma masiva implicó que cada uno de éstos tuviera un mínimo de características comunes para garantizar la rentabilidad de las operaciones.

La masificación de la producción provocó también la estandarización de las aspiraciones y deseos de los compradores. A finales del siglo XIX y principios del XX, la producción de bienes y productos se vio optimizada con los estudios de tiempos y movimientos realizados por Frederick W. Taylor. Con sus propuestas de trabajo, la estadística cobró gran importancia como una herramienta para el control de la calidad. Adicionalmente, las grandes guerras terminaron de dar un impulso definitivo al concepto de calidad, ya que la necesidad de producir enormes suministros bélicos sólo era factible si se disponía de procesos controlados.

El término marketing propiamente dicho comenzó a usarse en Estados Unidos e indicaba la actividad de penetración en el mercado (to go into the market). De acuerdo con Bartels (1988), el término pudo haber sido acuñado por el profesor E. D. Jones, quien impartió un curso titulado "The distributive and regulative industries of the United States" en la Universidad de Michigan en 1902, en cuyo folleto descriptivo se utilizó por vez primera el término marketing.

La expansión de las economías durante la etapa de la posguerra llevó a las industrias a buscar la producción de bienes con cero errores, lo que con el tiempo llegó a de- 
nominarse control de calidad. Aunado a lo anterior, en el último tercio del siglo $\mathrm{xx}$, apareció el concepto de aseguramiento de la calidad, el cual buscaba la reducción de los costos de producción a través de la prevención de errores y de la competitividad a que esto daba lugar.

Así pues, hacia finales del siglo XX y principios del XXI, el concepto se ha transformado en calidad total, en el cual la integración de las necesidades de los clientes lleva a los denominados procesos de mejora continua. Esta identificación e integración de necesidades es lo que hace de la mercadotecnia un elemento vigente en nuestros días.

Sin embargo, también es pertinente señalar que, a lo largo del tiempo, la mercadotecnia se ha visto empañada por las prácticas inescrupulosas de compañías y personas que han visto en sus técnicas un instrumento que brinda la posibilidad de embaucar y engañar al consumidor. Como ejemplo de lo anterior, podemos ver la demanda de un billón de dólares contra la compañía Johnson \& Johnson, que tiene que ver con las falsas afirmaciones sobre la seguridad del medicamento Risperda, el cual es producido por la empresa (Loftus, 2011).

Sucesos como éste hacen que, ante amplios sectores de la sociedad, la mercadotecnia no tenga una buena imagen ya que se le acusa de crear necesidades en el consumidor, propiciar la producción de bienes irracionales o, como en el caso señalado, mentir sobre las propiedades de un producto o minimizar sus riesgos.

De hecho, Licata (2007) señala que la opinión negativa sobre la mercadotecnia lleva ya mucho tiempo, y cita como un ejemplo el hecho de que en la Europa del siglo XVIII era común el envío por correo de artículos no solicitados bajo el supuesto de que los consumidores preferirían evitar el 
esfuerzo de devolver los productos y, por lo tanto, los conservarían y pagarían por ellos.

Para otros estudiosos del fenómeno, la mercadotecnia es un tanto confusa. En este sentido, Prada (2002) refiere que un gran número de críticos sociales vinculan la mercadotecnia con la práctica denominada planificación de la obsolescencia, que significa que cada cierto tiempo se presenta una nueva versión de un mismo producto, con lo cual se obliga a un consumo exagerado del mismo. De ahí que autores como Pereira (2008) reconozcan que en general los consumidores definen a la mercadotecnia como el "proceso diseñado a ayudar a las compañías a vender más".

Esta percepción fue confirmada con un estudio realizado en 2004 por la consultora de negocios Yankelovich Partners Inc., en el cual se señala que hay una creciente resistencia y negatividad hacia la mercadotecnia (Tabla 1).

Tabla 1

\begin{tabular}{|c|c|c|c|}
\hline \multicolumn{2}{|c|}{$\begin{array}{l}1964 \text { American Advertising } \\
\text { Association }\end{array}$} & \multicolumn{2}{|c|}{2004 Yankelovich Study } \\
\hline \multicolumn{2}{|c|}{ Opinión sobre el marketing } & \multicolumn{2}{|c|}{ Opinión sobre el marketing } \\
\hline Favorable & $41 \%$ & Positiva & $28 \%$ \\
\hline Desfavorable & $14 \%$ & Negativa & $36 \%$ \\
\hline Neutral & $34 \%$ & Neutral & $36 \%$ \\
\hline
\end{tabular}

Fuente: Abu-Shalback (2004: 5).

La percepción negativa acerca de la mercadotecnia ha empezado a cambiar en la medida en que las organizaciones públicas han comenzado a desarrollar lo que se conoce como la mercadotecnia social, aspecto que se analizará en el siguiente apartado. 


\section{LA MERCADOTECNIA SOCIAL}

La introducción de la mercadotecnia en el ámbito de las instituciones de carácter no lucrativo, tales como museos, iglesias y bibliotecas, entre otras, se da en 1969, a partir del artículo publicado por Philip Kotler, titulado "Broadening the Concept of Marketing".

Hacia la década de los setenta ya había una preocupación por hacer crecer el concepto de marketing, y fueron Kotler y Zaltman, en 1971, quienes sugirieron que este concepto debería ser ampliado a fin de incluir organizaciones distintas de las empresas, bajo la premisa de que "la mercadotecnia social es el diseño, implementación y control de programas pensados para influir en la aceptación de ideas sociales" (Kotler, 1971: 3).

De acuerdo con Andreasen, el marketing social se refiere a la aplicación de las técnicas del marketing comercial para llevar a cabo el análisis, planeación, ejecución y evaluación de programas diseñados para influir en el comportamiento voluntario de las personas y, de esta forma, mejorar el bienestar personal e incidir en prácticas benéficas para la sociedad (Andreasen, 1995). En este sentido, la mercadotecnia social maximiza la sensibilización hacia las expectativas, necesidades y deseos de los usuarios; ayuda a mejorar la imagen de los servicios públicos y sirve para atraer recursos; fomentar una filosofía de calidad total, y permitir el desarrollo de una ventaja competitiva.

De manera específica, respecto al ámbito bibliotecológico, es factible rastrear la influencia de la mercadotecnia desde finales del siglo XVII, cuando aparece en la literatura especializada el señalamiento de que el usuario es el centro de toda actividad bibliotecaria (Gupta, 2002: 25). 
A partir de ahí, en mayor o menor medida, con mayor o menor claridad, este concepto ha permeado las funciones y actividades bibliotecarias; si bien no fue sino hasta la segunda mitad del siglo xx que la profesión empezó a contar con textos que abordaban directamente el papel de la mercadotecnia en la satisfacción de las necesidades de los usuarios de las bibliotecas.

En este marco, se publican diversas obras alusivas al tema, entre las que destacan: la de Crawford, Performance Measurement in Library and Information Services (1966); la de De Prospo, Altman y Beasley, Performance Measures for Public Libraries (1973), y la de Totterdell y Bird, The effective library (1976). Por su parte, en 1977, apareció el artículo "Causes and Dynamics of User Frustration in an Academic Library", de Saracevic, en el cual proponía centrar las actividades bibliotecarias en torno a los usuarios.

Los textos citados tienen como denominador común la postura referente a colocar la satisfacción de los usuarios como el objetivo que tiene que alcanzar cualquier sistema de evaluación y mejora continua de una biblioteca. No obstante lo mencionado, no fue sino hasta la aparición, también en 1977, de la obra The Measurement and Evaluation of Library, cuando la evaluación de servicios bibliotecarios se estableció como una función permanente de las bibliotecas. Su autor, F. W. Lancaster, introdujo de una forma didáctica la evaluación de los procesos y servicios bibliotecarios.

De forma paralela a los títulos enunciados, los cuales abordaban la importancia de centrar los procesos de evaluación en la satisfacción de los usuarios, aparecieron textos enfocados directamente a promover el desarrollo de la mercadotecnia en las bibliotecas. El primero de ellos fue un artículo de Kotler considerado como clásico, "Broadened the Concept of Marketing", publicado en 1969 en el Journal 
of Marketing, el cual facilitó la adopción de los conceptos y herramientas de la mercadotecnia en instituciones no lucrativas, al enfatizar el concepto de que los servicios deben desarrollar la lealtad de los consumidores para lograr establecer relaciones de largo plazo.

En 1975, Kotler amplió sus conceptos en el libro Marketing for Non profit Organizations y, un año después, apareció en la Encyclopedia of Library and Information Science el artículo "Marketing Scientific and Technical Information", el cual señala que el uso de las técnicas de la mercadotecnia pueden asegurar el crecimiento y desarrollo de los sistemas de información.

En 1981 apareció en el Library Journal un reporte titulado "Beyond Public Relations: Marketing for Libraries", que señala que si bien la mercadotecnia no es la panacea para resolver todos los problemas de una biblioteca, sí provee de un buen arsenal para facilitar la planeación bibliotecaria. Ese mismo año, Robert Usherwoods publicó el libro The Visible Library, donde exhorta a las bibliotecas a mantener un alto perfil ante la sociedad, y de esta forma garantizar los fondos futuros que permitan su sostenimiento. Posteriormente, en 1984, Darlene Weingand publicó Marketing for Libraries and Information Agencies, texto que presentaba una serie de modelos para integrar la mercadotecnia a las labores bibliotecarias; y en 1988, Elizabeth Wood sacó a la luz Strategic Marketing for Libraries: a Handbook, guía fundamental para entender cómo los principios de la mercadotecnia mejoran los procesos de planeación de una biblioteca.

En los años noventa, The Association for Information Management (ASLIB) contribuyó mucho a la adopción de la mercadotecnia en las bibliotecas con sus obras Marketing: a how to do Manual for Librarians (1992) y How to Market your Library Services Effectively (1994). Adicionalmente, 
en el Reino Unido, en 1993, la Library Association publicó Marketing Concepts for Libraries and Information Services, el cual es pródigo en ejemplos exitosos de la aplicación del cybermarketing, e-mail marketing y relationship marketing. Por su parte, Cristine Koontz, en 1997, publicó Library Facility Siting and Location Handbook, el cual presenta la forma de entender el mercado de una biblioteca a través de identificar a los potenciales usuarios usando información demográfica. De la misma manera, en 1999, Sheila Webber, en Library and Information Work Worldwide, hace una importante contribución para entender las actitudes de los bibliotecarios ante la mercadotecnia.

Durante el nuevo siglo, los títulos más relevantes han sido los publicados por la International Federation of Library Associations and Institutions (IFLA), uno de los cuales fue publicado en 2005: e-learning for Management and Marketing Libraries, el cual tiene una aportación muy importante en la integración de la mercadotecnia dentro de la educación bibliotecológica. Otro texto de la IFLA que ha sido fundamental en esta nueva centuria es Marketing in Libraries and Information Services: International Perspectives, ya que proporciona un panorama global del estado del arte de la mercadotecnia aplicada en la bibliotecas.

DIFERENCIAS ENTRE LA MERCADOTECNIA COMERCIAL Y LA SOCIAL

Es importante destacar que, si bien ambas concepciones acerca de la mercadotecnia se asumen con herramientas y conceptos muy similares, el objetivo de la mercadotecnia comercial es identificar lo que la gente quiere y cuándo lo quiere para, de esta forma, poder proporcionárselo; por lo 
tanto, no es guiada por valores sino por intereses de rentabilidad. A este respecto, Wood indica que en un entorno comercial los clientes intercambian dinero por bienes y servicios, mientras que bajo el concepto de mercadotecnia social el intercambio no se basa en bienes tangibles sino en la adopción de ideas o el rechazo de conductas (Wood, 2008). Kotler, a su vez, señala que la mercadotecnia social comprende los esfuerzos por cambiar el comportamiento público por otro que la sociedad estime deseable (Kotler, 2004); de esta manera, en la actualidad no es sólo se necesita la comunicación de ideas sino influir en conductas. El cambio de conductas es la razón de ser de la mercadotecnia social.

Hastings (2011) establece que una campaña de mercadotecnia social no debe ser operada por una empresa comercial, ya que en el fondo lo que busca la compañía es incrementar sus ganancias y no mejorar la salud pública. Por su parte, Gordon (2011) va más allá y señala un nuevo tipo de mercadotecnia social: la socialmente responsable y que busca ayudar a regular las prácticas comerciales dañinas para la sociedad.

De acuerdo con lo mencionado, la mercadotecnia socialmente responsable no sólo ayuda a entender los efectos dañinos de la mercadotecnia comercial, sino que puede ser usada para cambiar políticas públicas y establecer regulaciones para obtener un bien social. Por ejemplo, a escala mundial, el 3.8\% de las muertes y el $4.6 \%$ de las lesiones son producidas como consecuencia del abuso del alcohol. Con estos datos, ha sido posible centrar la discusión no sólo en las consecuencias del consumo de alcohol sino en la importancia de regular de forma más estricta la venta de alcohol así como las campañas de promoción de este producto (Gordon,2011). 
En síntesis, la mercadotecnia socialmente responsable busca examinar las actividades e impactos de la mercadotecnia comercial; es decir, se orienta hacia la comercialización de las políticas públicas en beneficio de las causas sociales.

A partir de lo expuesto, se reconoce que la mercadotecnia social es una valiosa herramienta administrativa para el diseño, elaboración y prestación de los servicios para las instituciones no lucrativas. Cuando esto se aplica en el entorno de las bibliotecas, se le denomina mercadotecnia de la información (Bautista, 2000).

En torno a la mercadotecnia de la información existen varias creencias erróneas. La primera de ellas es que los servicios de una biblioteca no deben de mercadearse; la segunda es la consideración de que la mercadotecnia es sólo aplicable a los servicios privados; la tercera se refiere a lo antiético de su utilización en la promoción de los servicios bibliotecarios; una cuarta señala lo poco que ofrece la mercadotecnia a las bibliotecas; y finalmente, se cree equivocadamente que la calidad es algo implícito en los servicios bibliotecarios, por lo que no es necesario evaluarlos ni mercadearlos.

No obstante, la futura viabilidad de las bibliotecas dependerá de su propia capacidad para demostrar, de una forma dinámica y continua, su valor ante la sociedad; y dicho valor sólo podrá ser reconocido si los instrumentos de la mercadotecnia son utilizados para este fin.

EL PLAN DE MERCADOTECNIA

El esquema básico para un plan de mercadotecnia se ilustra en la Figura 1. 
Figura 1

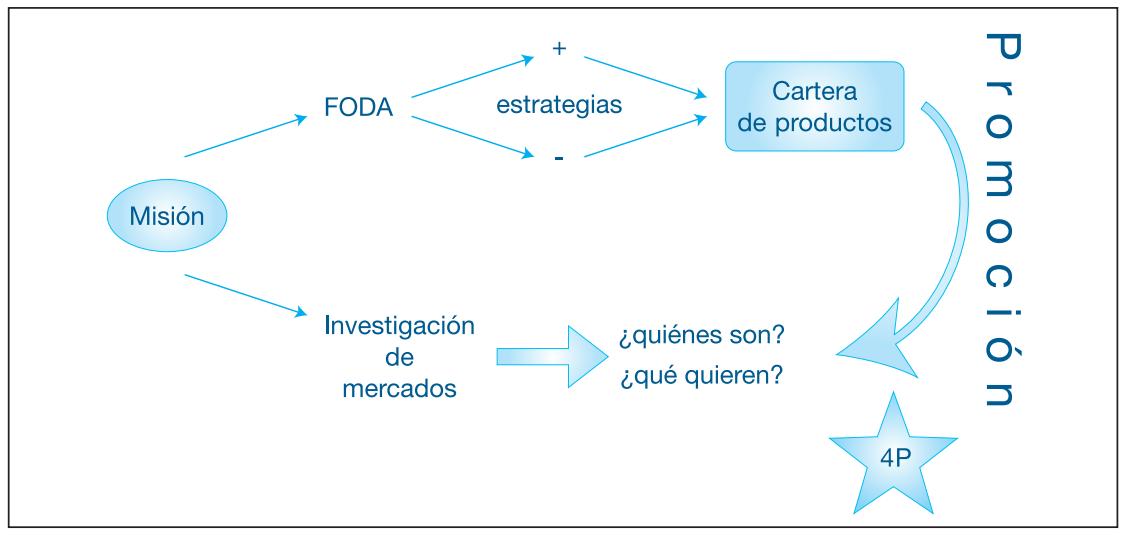

La misión es la frase que define el propósito o razón de ser de una organización. Una misión genera el compromiso colectivo para pasar de tratar de hacer las cosas bien a hacer lo correcto.

Es fundamental que la misión sea clara, concisa y que conteste con precisión las siguientes preguntas:

- ¿Qué se va a hacer? (oferta).

- ¿Para quién se va a hacer? (demanda).

- ¿Por qué nos van a elegir? (ventajas competitivas).

Un ejemplo de lo anterior es la misión de la compañía Nike:

Our mission is to carry on his legacy of innovative thinking, whether to develop products that help athletes of every level of ability reach their potential, or to create business opportunities that set Nike apart from the competition and provide value for our shareholders. ${ }^{1}$

1 Nike Inc. http://nikeinc.com/pages/about-nike-inc 
- ¿Qué se va a hacer? (oferta).

- Desarrollamos productos deportivos.

- ¿Para quién se va a hacer? (demanda).

- Atletas de todos los niveles.

- ¿Por qué nos van a elegir? (ventajas competitivas).

- Aplicamos un pensamiento innovador en lo que hacemos.

Una vez definida la misión, es importante comunicarla y explicitarla a todos los miembros de la organización. El publicar la misión refleja el compromiso real que se tiene por alcanzarla día a día.

Con base en la misión, se procede a desarrollar el FODA de la organización. El FODA (Fortalezas, Oportunidades, Debilidades y Amenazas) es una herramienta de la planeación estratégica que nos permite hacer un diagnóstico de la situación actual en la cual se encuentra la organización. Este diagnóstico es, junto con la investigación de mercados, el inicio de un proceso de mejora continua.

Mucha de la utilidad del FODA estriba en que sea una fotografía del momento actual de la organización. Referirse a situaciones pasadas o a un futuro deseable no ayuda en nada al diagnóstico. Hacer bien un FODA debería de ser como cuando, una mañana al despertar, nos paráramos desnudos frente al espejo y describiéramos lo que vemos.

El FODA se plasma en la matriz expuesta en la Tabla 2.

Tabla 2

\begin{tabular}{|c|c|c|}
\cline { 2 - 3 } \multicolumn{1}{c|}{} & Positivos & Negativos \\
\hline Internos & Fortalezas & Debilidades \\
\hline Externos & Oportunidades & Amenazas \\
\hline
\end{tabular}


Fortalezas y debilidades se refieren a los recursos de la organización. Por ejemplo, unas buenas instalaciones serían una fortaleza. Una plantilla de personal sin formación en bibliotecología o desmotivado, sería una debilidad. Sobre las fortalezas y debilidades se tiene algún grado de control.

Oportunidades y amenazas son cuestiones externas que afectan a la organización. El Programa Nacional de Lectura y Escritura impulsado por la Secretaría de Educación Pública (SEP) puede ser una oportunidad para una biblioteca pública. Para una biblioteca universitaria que compra muchos libros en inglés, una devaluación sería una amenaza. Sobre las oportunidades y amenazas no se tiene ningún grado de control, sólo se pueden aprovechar o buscar minimizar sus efectos negativos.

Al hacer un FODA es muy importante saber distinguir lo importante de lo no importante: por ejemplo, mientras que para una biblioteca especializada la limpieza de los baños es algo que se da por sentado, para una biblioteca pública puede ser un factor crucial que permita una mayor afluencia de usuarios, ya que muchas de estas bibliotecas se encuentran en parques públicos. El hecho de que acudan a los baños de la biblioteca es una gran oportunidad de buscar estrategias para acercar a los visitantes a la lectura y a los recursos de la biblioteca.

Mientras que para una pequeña biblioteca pública de 2,000 libros y 3 bibliotecarios la existencia de manuales de procedimientos puede no ser un factor clave para su funcionamiento, para una biblioteca universitaria de $80 \mathrm{mil} \mathrm{li-}$ bros y una plantilla de 30 personas, la existencia de dichos manuales es forzosa para garantizar la uniformidad en la prestación de los servicios. 
A continuación se presentan algunos ejemplos de cómo categorizar los recursos de la organización y los factores exteriores que la afectan.

\section{Fortalezas}

- Personal

- Experiencia; preparación; liderazgo; trabajo en equipo; espíritu de servicio.

- Organización y servicios

- Servicios de calidad; orientación a usuarios; relaciones con la comunidad.

- Colecciones

- Actualización; cobertura; variedad; especiales; electrónicas, presupuestos.

- Infraestructura

- Instalaciones; cómputo; sistemas de apoyo; seguridad.

- Consorcios

- Integración en programas de cooperación.

\section{Debilidades}

- Personal

- Ausencia de profesionales; pocas plazas; fatiga; desmotivados; sobrecargas de trabajo.

- Organización y servicios

- Estructura fragmentada; no aplicación de normas; no control de calidad; no retroalimentación; aislamiento. 
- Colecciones

- Desactualizadas; poca variedad; ausencia de estadísticas; poco presupuesto; deterioro.

- Infraestructura

- Instalaciones inadecuadas; compartidas; subutilizadas; cómputo desactualizado; no hay sistemas de apoyo o seguridad.

- Consorcios

- Nula participación.

\section{Oportunidades}

- Cambio de planes de estudio.

- Reorganización institucional.

- Programas de educación a distancia.

- Programa de fomento a la lectura.

- Tecnologías de información.

- Surgimiento de consorcios.

- ONG.

- Donantes.

\section{Amenazas}

- Legislación sobre derechos de autor.

- Licencias de uso.

- Dificultad para conservar al personal.

- Vida corta del software y del hardware.

- Recortes presupuestales.

- Incremento en el costo de los materiales.

- Ausencia de autonomía. 
Es importante señalar que desarrollar un FODA es un ejercicio difícil ya que su utilidad estará en función de la objetividad que apliquemos al análisis y de la experiencia que tengamos en la aplicación de esta técnica. Es muy recomendable que el FODA sea un ejercicio donde se recojan las opiniones y observaciones del equipo de trabajo de la institución.

Hagamos una primera aproximación al FODA de nuestra unidad de información; por favor llene la matriz correspondiente a la Figura 2.

Figura 2

FODA

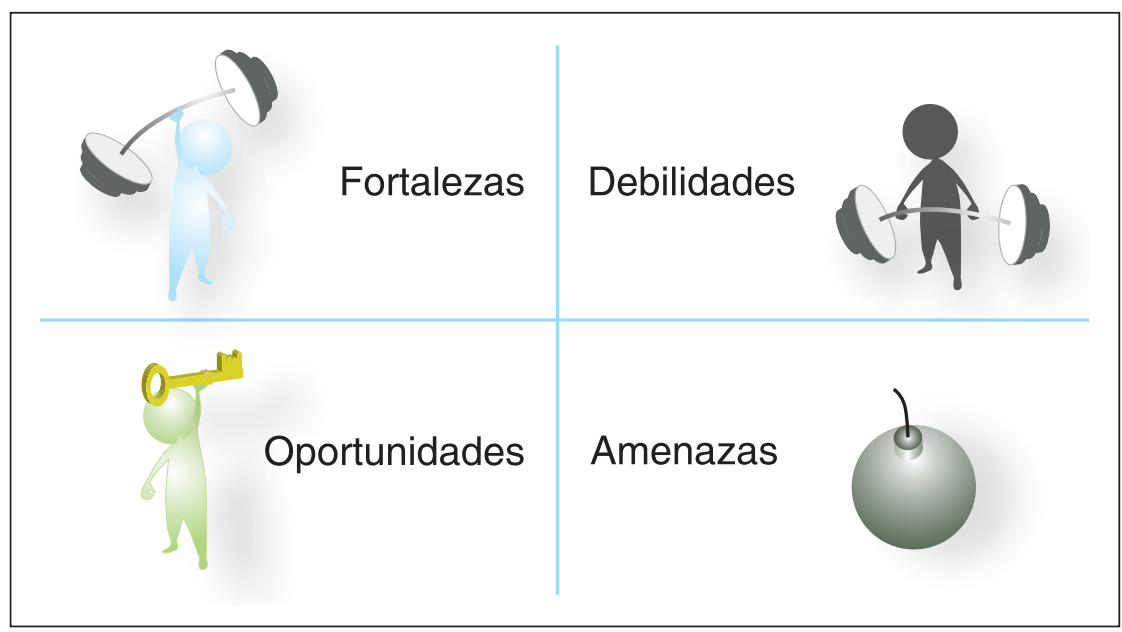

Un FODA correctamente aplicado nos dará los elementos para contestar las siguientes preguntas:

- ¿Qué deberíamos hacer más?

- ¿Qué deberíamos de hacer menos?

- ¿Qué deberíamos dejar de hacer?

- ¿Qué deberíamos empezar a hacer? 
Una vez que se han integrado en la matriz todos los recursos de la organización, así como los factores que pueden influir sobre ella, es necesario establecer los cursos alternos de acción (estrategias) que nos permitirán alcanzar eficientemente la misión institucional.

Las estrategias se agrupan bajo cuatro categorías:

- Ofensivas (fortalezas + oportunidades).

- Defensivas (fortalezas + amenazas).

- De reorientación (debilidades + oportunidades).

- De supervivencia (debilidades + amenazas).

La integración de las estrategias al FODA se hace con base en la matriz desarrollada que se presenta en la Tabla 3.

Tabla 3

\begin{tabular}{|c|c|c|}
\hline Extrenas Internas & $\begin{array}{ll} & \text { Fortalezas } \\
\text { F1 } & \\
\text { F2 } & \\
\text { F3 } & \end{array}$ & $\begin{array}{ll} & \text { Debilidades } \\
\text { D1 } & \\
\text { D2 } & \\
\text { D3 } & \end{array}$ \\
\hline $\begin{array}{l}\text { Oportunidades } \\
\mathrm{O} 1 \\
\mathrm{O} 2 \\
\mathrm{O} 3\end{array}$ & $\begin{array}{l}\text { Estrategias ofensivas } \\
\text { (maximizar } \mathrm{F} \text { y O) }\end{array}$ & $\begin{array}{l}\text { Estrategias reorientación } \\
\text { (minimizar D y maximizar O) }\end{array}$ \\
\hline $\begin{array}{ll} & \text { Amenazas } \\
\text { A1 } & \\
\text { A2 } & \\
\text { A3 } & \end{array}$ & $\begin{array}{c}\text { Estrategias defensivas } \\
\text { (maximizar F y minimizar A) }\end{array}$ & $\begin{array}{c}\text { Estrategias } \\
\text { de supervivencia } \\
\text { (minimizar D y A) }\end{array}$ \\
\hline
\end{tabular}

Donde F1 corresponde a la fortaleza uno, O1 a la oportunidad número uno, A1 a las amenaza número uno, y así sucesivamente. 
Como ejemplo, asumamos que la biblioteca cuenta con un personal con muy buena actitud de servicio (F1 o Fortaleza uno). Si buscamos establecer una estrategia ofensiva, es decir acciones que nos permitan aprovechar una fortaleza al combinarla con una oportunidad, podemos combinarla con O1, que es la Oportunidad uno, existencia de cursos de educación a distancia, y obtenemos la primera estrategia ofensiva, que sería promover la inscripción del personal a cursos de educación a distancia. El FODA desarrollado de este ejemplo quedaría como se plantea en la Tabla 4.

Tabla 4

\begin{tabular}{|c|c|c|}
\hline Extrenas Internas & $\begin{array}{l}\text { Fortalezas } \\
\text { F1 Buena actitud del personal } \\
\text { F2 } \\
\text { F3 }\end{array}$ & $\begin{array}{ll} & \text { Debilidades } \\
\text { D1 } & \\
\text { D2 } & \\
\text { D3 } & \end{array}$ \\
\hline Oportunidades & $\begin{array}{c}\text { Estrategias ofensivas } \\
\text { (maximizar } \mathrm{F} \text { y O) }\end{array}$ & $\begin{array}{l}\text { Estrategias reorientación } \\
\text { (minimizar D y maximizar O) }\end{array}$ \\
\hline $\begin{array}{l}\text { O1 Cursos de educación } \\
\text { a distancia } \\
\mathrm{O} 2 \\
\mathrm{O} 3\end{array}$ & $\begin{array}{l}\text { F1 + O1 Promover la inscripción } \\
\text { del personal a cursos de } \\
\text { educación a distancia }\end{array}$ & \\
\hline $\begin{array}{ll} & \text { Amenazas } \\
\text { A1 } & \\
\text { A2 } & \\
\text { A3 } & \end{array}$ & $\begin{array}{l}\text { Estrategias defensivas } \\
\text { (maximizar F y minimizar A) }\end{array}$ & $\begin{array}{c}\text { Estrategias } \\
\text { de supervivencia } \\
\text { (minimizar D y A) }\end{array}$ \\
\hline
\end{tabular}

Una vez que hemos desarrollado el FODA, es posible definir la cartera de productos de la organización.

En 1970 el Boston Consulting Group propuso la cartera o portafolio de productos (The Product Portfolio) como un instrumento que permite clasificar todos los productos de una organización. 
La matriz propuesta permite conocer de un vistazo el grado de desarrollo de los productos y, en función de esto, poder tomar decisiones para apoyar a los productos más rentables y eventualmente eliminar a los que ya no representan interés para el consumidor.

De acuerdo con Arellano (2006), los productos ubicados en el cuadrante "Estrella" son aquellos de alto crecimiento en las ventas $\mathrm{y}$, por lo tanto, permiten una alta penetración en el mercado. El cuadrante "Niño problema" o "Signo de interrogación" alberga a los productos que pueden tener un buen crecimiento en las ventas, pero que representan una incógnita a mediano plazo, esto es, que no se sabe a ciencia cierta si serán rentables, o bien, terminarán desapareciendo. Los productos ubicados en el cuadrante "Vaca lechera" representan a aquellos en donde hay una buena recepción de los consumidores por ser productos de probada calidad, pero que tienen un crecimiento lento. Finalmente, tenemos el cuadrante "Perro", donde se ubican aquellos productos con un crecimiento débil o nulo y por lo tanto su penetración en el mercado es mínima (Figura 3).

Figura 3

Catálogo de productos

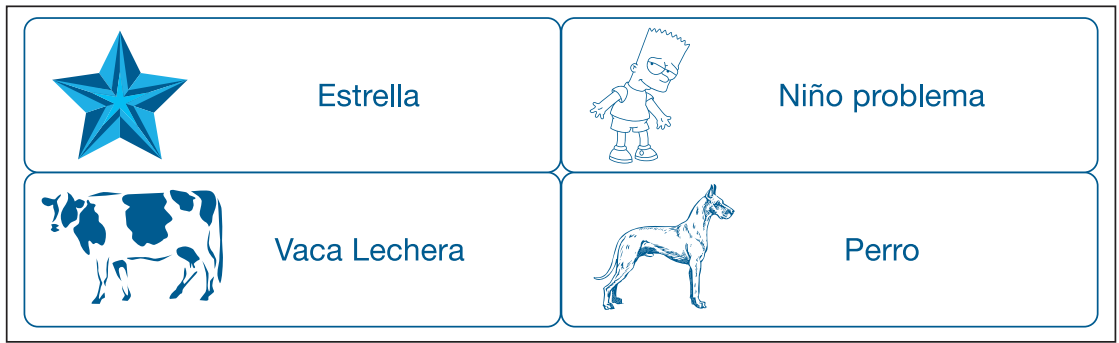

Para un lector avispado resultará claro que en el FODA ya realizamos una preclasificación al determinar nuestras fortalezas y debilidades. 
Todos aquellos recursos de la unidad de información que sean consumidos por nuestros usuarios se denominan productos, y deberán ser integrados al catálogo de productos.

Por ejemplo, el préstamo a domicilio podría ser ubicado en el cuadrante "Vaca lechera", ya que es un servicio consolidado y reconocido por los usuarios; si bien no tiene el glamour de los servicios electrónicos de consulta al texto completo de artículos y libros, es un producto consumido permanentemente. A su vez, la consulta a los e-books podría ser en este momento nuestro producto estrella. La digitalización de colecciones estaría en el cuadrante "Niño problema" si es que no tuviéramos la certeza de que es un proyecto que terminará despegando y será rentable. Finalmente, un ejemplo de un producto "Perro" podría ser el archivo vertical si es que fuera un conjunto de documentos atiborrados en un archivero sin ningún tipo de organización.

En cada uno de los cuadrantes puede haber más de un producto y, al igual que el FODA, hay que entender que son radiografías de la situación actual de la organización; por lo tanto es necesario actualizarlos con frecuencia, sobre todo si hemos experimentado cambios importantes.

Una vez que una organización cuenta con su cartera de productos, debe definir qué productos conservará y cuáles eliminará. A continuación canalizará recursos hacia los productos que se conservaron con el objeto de ganar mayor penetración en el mercado, esto es, que sean conocidos y consumidos por los clientes.

La estrategia de promoción de un producto se hace dentro de un esquema denominado mezcla de la mercadotecnia, Mix Marketing, en inglés. Esta mezcla implica la integración de 4 P (Figura 4). 
Figura 4

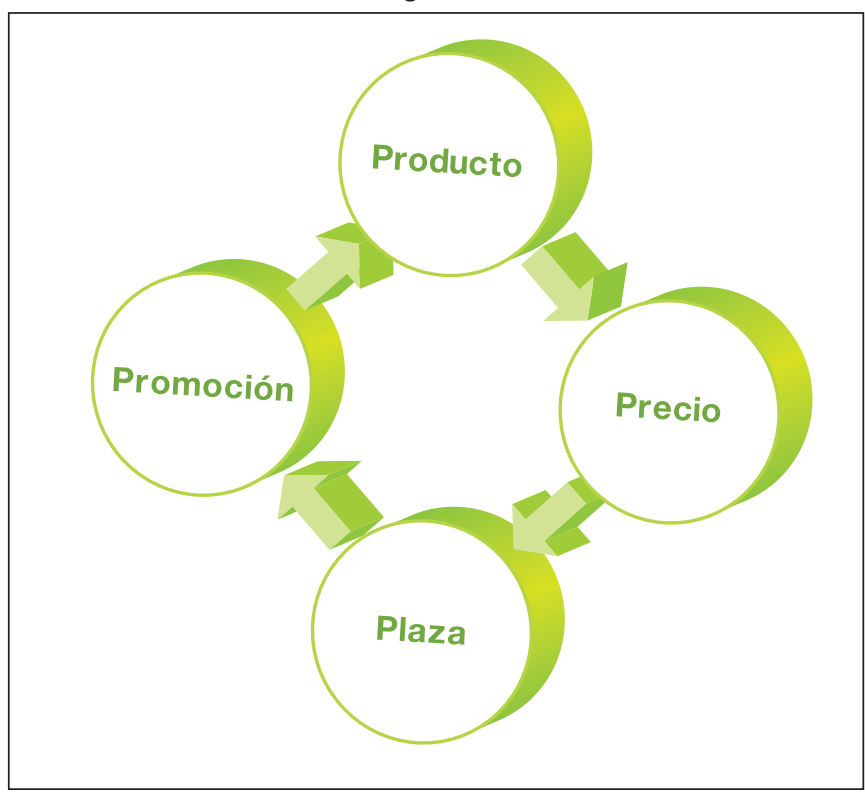

El precio es el valor económico que la organización le concede a un producto o servicio, y es también el punto de equilibrio entre los intereses de las dos partes; asimismo, representa la cifra más baja que el vendedor está dispuesto a aceptar por desprenderse de su producto y es la cantidad más alta que el consumidor está dispuesto a pagar.

No sólo existen los precios monetarios; están también los llamados precios sociales o valores simbólicos que se relacionan con el esfuerzo suplementario que debe aportar el consumidor para tener acceso a los servicios. Por ejemplo, para llegar a una biblioteca pública quizá el usuario tiene que transportarse durante dos horas y, ya estando ahí, armarse de paciencia para poder llevar el libro a casa ya que el servicio es muy burocratizado. En este caso el precio que paga el usuario es muy alto y seguramente, si un día tiene 
la oportunidad de utilizar otra fuente de información más accesible, cambiará de proveedor.

La plaza constituye todos los espacios físicos, virtuales o temporales que la organización utiliza para hacer accesibles sus productos o servicios. Estos puntos de acceso pueden ser las instalaciones de la biblioteca, la página web y las actividades de extensión, como una feria del libro o el servicio de bibliobús.

La promoción es toda comunicación persuasiva que mejora la identificación y utilización de un servicio o producto.

Algunas personas ven la promoción como algo frívolo, innecesario y menos importante que otras funciones administrativas; ellas piensan: "Si hacemos bien nuestro trabajo, ¿por qué no ha de ser reconocido?" Sin embargo, la promoción es esencial para una unidad de información. Es la actividad que permite que nuestra comunidad de usuarios conozca los servicios y programas de la biblioteca. Estimula la demanda por nuevos servicios, incrementa la importancia y visibilidad de la organización; asimismo, es un argumento para obtener presupuestos.

La promoción se puede realizar a través de:

- Anuncios y pósters.

- Volantes y boletines.

- Grupos de amigos de la biblioteca.

- Páginas web.

- Presentaciones públicas.

- Un personal capacitado y con alto espíritu de servicio.

Ojo: no siempre las estrategias de promoción funcionan, ¿qué tan conveniente es anunciar alimento para gatos en la televisión nacional, si sólo el $20 \%$ de la población tiene un gato? 
MIOPÍA DEL MARKETING

De acuerdo con la American Academy of Optometry, la miopía es un error en el enfoque visual que causa dificultad de ver los objetos distantes. En el ámbito de la mercadotecnia, fue Theodore Levitt quien en 1960 propuso el concepto Marketing Myopia. En un artículo aparecido en la Harvard Business Review, el profesor Levitt formuló la pregunta que sacudió a muchos gerentes de su tiempo: “¿En qué negocio está usted realmente?"

Es memorable la respuesta del presidente de la Association of American Railroads, quien señaló que su negocio eran los trenes (enfoque desde el producto). Con este razonamiento es fácil comprender los problemas que enfrentó esta industria, ya que a mitad del siglo pasado muchos de los servicios que prestaba fueron absorbidos por las compañías de autobuses y las líneas aéreas, que se definieron como empresas que transportaban personas y mercancías (enfoque desde el mercado).

Con algunos descalabros, la industria del cine entendió que su negocio no era la creación de películas (enfoque desde el producto), sino que su negocio era el entretenimiento (enfoque desde el mercado).

¿Cuál es el negocio (propósito) de una biblioteca? ¿Prestar libros? o ¿brindar servicios de información con calidad y oportunidad?

El definir equivocadamente nuestro nicho de negocio puede tener consecuencias desastrosas para la organización. 


\section{BIBLIOGRAFÍA}

Abu-Shalback Zid, L. (2004), "Marketing Under Fire", en Marketing Management, vol. 13, núm. 4, pp. 1-5.

Andreasen, A. (1995), Marketing Social Change: Changing Behavior to Promote Health, Social Development, and the Environment, New York, Jossey-Bass.

Arellano, R. (2006), Marketing: enfoque América Latina, México, McGraw-Hill.

Bartels, R. (1988), The History of Marketing Thought, $3^{a}$ ed., Columbus, OH, Publishing Horizons.

Bautista, E. (2000), "La mercadotecnia de la información en las bibliotecas universitarias", en Biblioteca Universitaria: Nueva Época, vol. 3, núm. 2, pp. 108-117.

Gordon, R. (2011), "Critical Social Marketing: Definition, Application and Domain", en Journal of Social Marketing, vol. 1, núm. 2, pp. 82-99.

Gupta, D. y A. Jambhekar. (2002), "What is Marketing in Libraries? Concepts, Orientations, and Practices", en Information Outlook, Nov. 6, 11, pp. 24-30

Hastings, G. y Angus, K. (2011), "When is Social Marketing not Social Marketing?", en Journal of Social Marketing, vol. 1, núm. 1, pp. 45-53.

Kotler, P. (1969), "Broadening the Concept of Marketing”, en Journal of Marketing, vol. 33, núm. 1, pp. 10-15.

Kotler, P. (2004), Las preguntas más frecuentes sobre marketing, México, Norma.

Levitt, T. (1960), "Marketing Myopia”, en Harvard Business Review (July-August), pp. 45-56. 
Licata, J. y Von Berger, C. (2007), "An Exploratory Study of Negative Option Marketing: Good, Bad or Ugly?", en International Journal of Bank Marketing, vol. 25, núm. 4, pp. 207-222.

Loftus, P. (2011). "Johnson \& Johnson Ordered to Pay $\$ 327 \mathrm{Mi}$ llion", en The Wall Street Journal, 4 June, pp.12-13.

Pereira, M. y Heath, M. (2008), "(Mis)trust in Marketing: a Reflection on Consumers' Attitudes and Perceptions", en Journal of Marketing Management, vol. 24, núm. 9-10, pp.1025-1039.

Prada Daza, R. (2002), "Análisis de la crítica social al marketing”, en Estudios Gerenciales, vol. 18, núm. 84, pp. 79-88.

Valenzuela, L. et al. (2006), "Evolución de marketing hacia la gestión orientada al valor del cliente: revisión y análisis", en Theoría: Ciencia, Arte y Humanidades, vol. 15, núm. 002, pp. 99-105.

Wood, E. y Young, V. (1988), Strategic Marketing for Libraries: a Handbook, Michigan, Greenwood Press. 


\title{
El comportamiento del usuario como consumidor de información
}

\author{
FERnANDO EdMUNDO GONZÁlEZ MORENO \\ Universidad de las Américas A.C. \\ Biblioteca
}

\section{INTRODUCCIÓN}

\begin{abstract}
Olomon (2006) define el comportamiento del consumidor como todos aquellos procesos que tienen lugar cuando un individuo selecciona y utiliza un producto, servicio, ideas o experiencias para satisfacer sus necesidades y deseos. Dicho comportamiento, de acuerdo con Hoffmann (2011), se presenta en tres fases:
\end{abstract}

1) La elección entre las alternativas previas a la compra.

2) La reacción del consumidor durante el consumo.

3) La evaluación de la satisfacción posterior a la compra.

Ahora bien, estas etapas no se dan en forma aislada. Con base en el paradigma ecológico -esquema vigente que explica cómo los seres humanos procesan la información-, podemos afirmar que las personas aprenden a partir de la interacción con otras personas y con su contexto. 
El ser humano desarrolla su cognición e inteligencia a través de las siguientes etapas:

- Procesos básicos: tienen que ver con la percepción a través de los sentidos y la atención que se les brinda a los estímulos.

- Procesos complejos: es el desarrollo del lenguaje y, con él, la formación de conceptos y la abstracción.

- Metacognición: es la capacidad para controlar nuestro razonamiento; esto es, darnos cuenta de cómo pensamos.

A través del tránsito en estas etapas, las personas van modificando su forma de pensar y, por ende, sus patrones de consumo. En procesos básicos, predomina la capacidad de adquirir información. En procesos complejos, se privilegia la retención del conocimiento. Finalmente, la metacognición favorece el uso consciente de la información adquirida y retenida previamente.

Tomando en cuenta lo anterior, queda claro que el acto de comprar un bien o servicio no es un acto mecánico, y que si repitiéramos ese acto más adelante podría verse modificada la decisión no sólo por la experiencia de compra sino también por la experiencia acumulada en todos los aspectos de nuestra vida.

Noel (2009) propone un modelo que ejemplifica lo antes expuesto (Figura 1). 
Figura 1

Modelo de comportamiento del consumidor

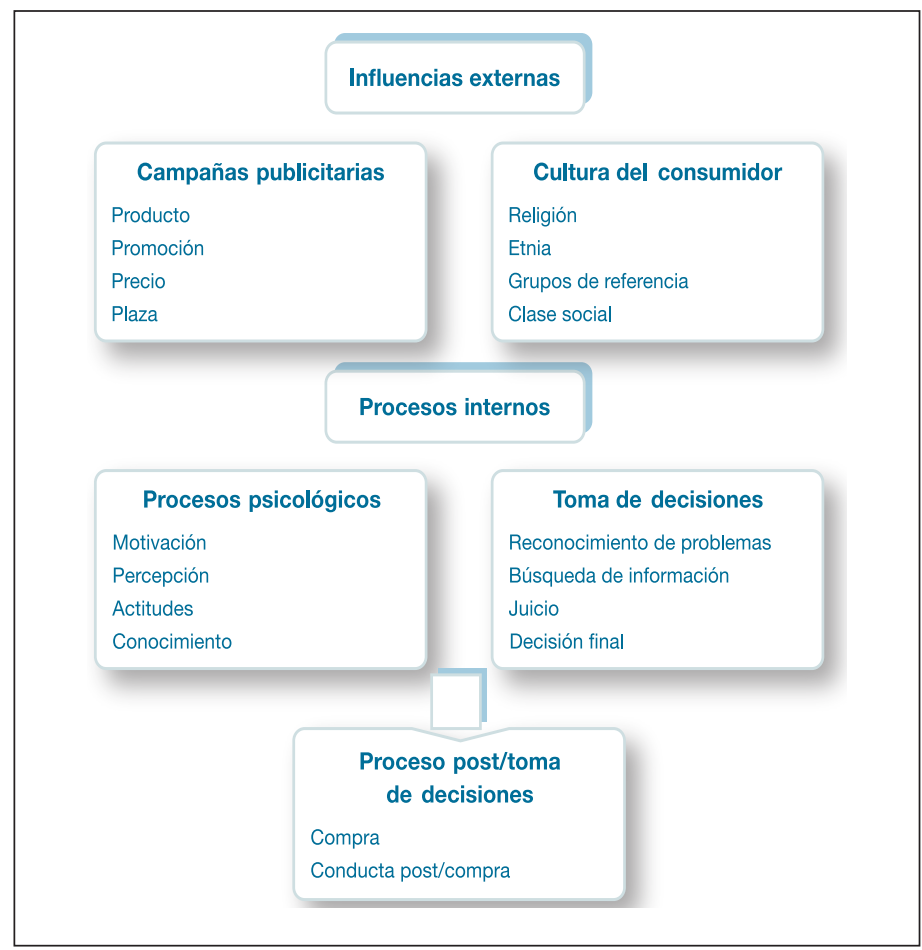

Dicho comportamiento también se ve influido por dos factores: las cualidades propias del producto y las expectativas que tenemos sobre él.

\section{CuAlidades}

Las cualidades trasmiten los beneficios de un producto o servicio. Hacen referencia a sus características y pueden ser inherentes (que ya las posee) o bien pueden ser adquiridas $\mathrm{y}$, por lo tanto, modificables con el paso del tiempo. 


\section{Cualidades de búsqueda}

Responden a las expectativas que se ha formulado previamente el cliente, como por ejemplo localizar en la biblioteca un libro que detalle los cuidados a los que se debe someter el lirio del Perú (astromelia), o bien, tener acceso a Internet a través de una conexión de banda ancha.

\section{Cualidades de experiencia}

Se destacan al momento de ejecutar la compra, y se refieren básicamente a características intangibles del servicio, como pueden ser la amabilidad del personal del módulo de préstamo o la tranquilidad de la sala de lectura.

\section{Cualidades de credibilidad}

Son referidas a través de un tercero, y tienen que ver con lo que se denomina marketing viral, donde las experiencias personales de compra son trasmitidas boca a boca a otros potenciales consumidores. Un ejemplo clásico es el estudiante de posgrado que recomienda ampliamente el servicio de la biblioteca "pero sólo el de la tarde, ya que los de la mañana son unos pesados".

\section{EXPECTATIVAS}

Una expectativa es la posibilidad razonable de que algo suceda. Remarcamos el término razonable pues, de lo contrario, estaríamos hablando de una esperanza.

Por ejemplo, un usuario puede tener la expectativa de encontrar el libro que requiere, ya que en el pasado ha encon- 
trado otros libros que ha buscado. Una esperanza sería que le dieran un trato amable al solicitar el servicio, ya que en esa biblioteca las filas para sacar en préstamo un libro son larguísimas y el trato del personal, digamos, no es muy cordial.

Una expectativa está fuertemente vinculada a una situación que es muy factible que se produzca. Cuando esto sucede, el individuo experimenta agrado y tranquilidad, y dado el caso de que supere lo esperado, el sentimiento será de alegría y aun de euforia. Por otro lado, cuando no se cubre la expectativa, el sentimiento puede ser de de insatisfacción.

De acuerdo con Hoffmann (2011), los clientes manejan al menos tres tipos de expectativas.

\section{Servicio pronosticado}

Refleja el nivel de servicio que el cliente piensa que le dan. Un ejemplo sería que el usuario asume que les prestarán los cuatro libros que solicite.

\section{Servicio deseado}

Esta expectativa es más alta porque parte del hecho de que el cliente espera que le den el servicio pronosticado y un poco más. El usuario obtiene los cuatro libros solicitados y además, al acercarse al mostrador, fue reconocido y llamado por su nombre; quizá hasta le recomendaron otro título y le permitieron que también lo llevara.

\section{Servicio adecuado}

Representa el mínimo de servicio que el cliente está dispuesto a aceptar. En nuestro ejemplo, el usuario aceptaría que le prestaron sólo tres de los cuatro libros solicitados, 
pero no una cantidad menor. También podría aceptar que el trato de los bibliotecarios fuera seco, pero no permitiría que fuera grosero o agresivo.

\section{Zona de tolerancia}

Comprende el espacio existente entre el servicio deseado y el servicio adecuado. En general, los clientes entienden y asumen que puede haber variaciones en la calidad del servicio ofrecido, y mientras que estas oscilaciones no rebasen el límite del servicio adecuado pueden ser aceptadas.

Resulta interesante el hecho de que un usuario puede modificar con amplitud sus expectativas de servicios pronosticados, deseados y adecuados si cambia de biblioteca.

Lo que en una biblioteca sería un servicio deseado, en otra apenas alcanzaría el rubro de adecuado; esto se debe precisamente a la amplia oferta bibliotecaria que encuentran los usuarios hoy en día. De acuerdo con el Instituto Nacional de Estadística y Geografía (INEGI), hacia el año 2012 había en México 13,308 bibliotecas (7,378 públicas, 5,702 escolares y 228 especializadas). En 17 años, el país pasó de 9,840 a 13,308 bibliotecas; un crecimiento de 35.2\%, 204 bibliotecas nuevas cada año, 17 bibliotecas nuevas cada mes. Esto puede explicar por qué los usuarios son cada día más exigentes y, ante una amplia oferta informativa, la zona de tolerancia disminuye, ya que los clientes no perdonan un servicio deficiente.

\section{SATISFACCIÓN DEL CLIENTE}

Es la medición de cómo los productos y servicios suministrados por una empresa cumplen o superan las expectati- 
vas del cliente. Farris (2010) la define como "el número de clientes, o el porcentaje del total de clientes, cuyo reporte de experiencia con una empresa, sus productos o sus servicios (ratings) excede los objetivos de satisfacción especificados.”

\section{Medición de la satisfacción al cliente}

Hoffman (2011) señala que la satisfacción del cliente se puede medir a través de dos métodos (Figura 2).

Figura 2

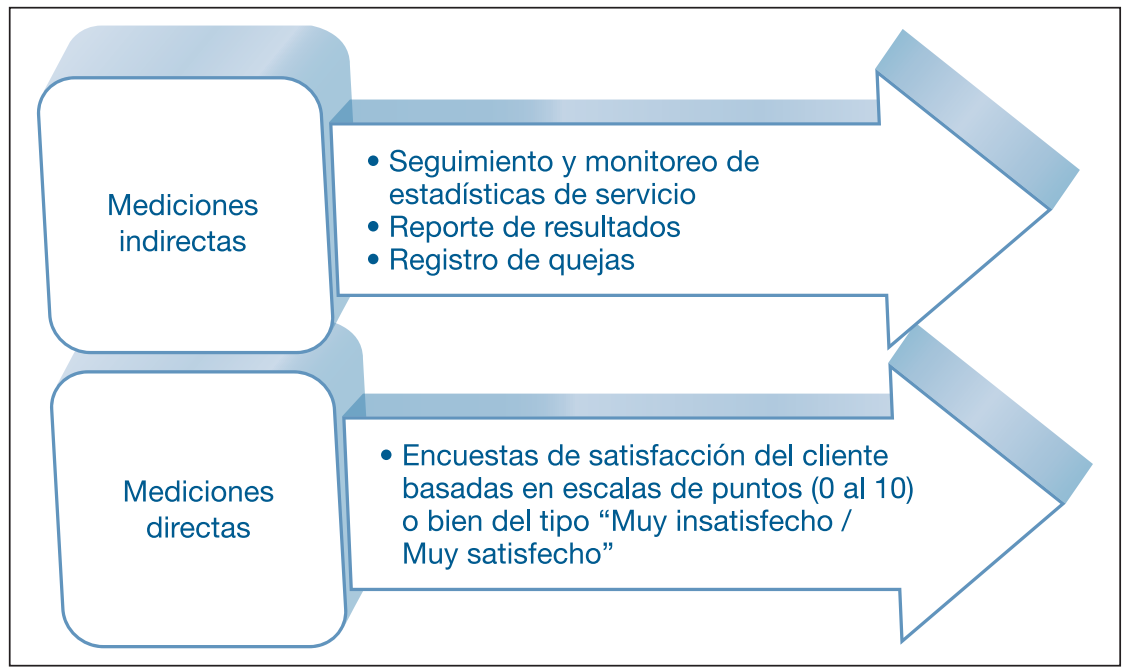

Las mediciones indirectas, por su naturaleza, son de carácter pasivo ya que buscan deducir grados de satisfacción con base en las variaciones de la cantidad de servicios prestados. Por ejemplo, una suposición puede ser que a mayor satisfacción con el servicio habrá un mayor número de transacciones. Esto puede ser cierto, o bien, puede deberse a la combinación de varios factores. Con respecto al análisis de 
quejas, su mayor riesgo es basarnos sólo en la opinión de "los que hablan" y dejar de lado a la "mayoría silenciosa", la cual puede estar satisfecha o no con el servicio.

Las mediciones directas brindan una mayor precisión para determinar la satisfacción de los clientes. En el capítulo siguiente, se abundará sobre estas herramientas, en particular el sistema estandarizado LibQual.

Vinculada estrechamente a la satisfacción del cliente encontramos la calidad en el servicio.

\section{Medición de la calidad del servicio}

Martin (2009) señala que aunque los servicios comúnmente son intangibles y a menudo elusivos, pueden ser vistos, escuchados y experimentados por los clientes. En razón de esto, la calidad de un servicio sólo puede ser entendida desde el punto de vista del cliente. Esta calidad debe ser definida a través de los ojos de los consumidores, los cuales tienden a agrupar el nivel de un servicio en dos grandes categorías (Figura 3).

Figura 3

\section{La dimensión procedimental}

- La estabilidad de un sistema para proveer productos y servicios

La dimensión personal

- Cómo se brinda el servicio a través de las conductas, actitudes v habilidades de comunicación del presonal 
La adopción de una perspectiva de servicio orientado al cliente implica asumir que:

- El cliente es el rey.

- El cliente es nuestra razón para existir.

- Sin clientes, no tenemos nada.

- Nuestros clientes definen nuestro negocio.

- Si no entendemos a nuestros clientes, no entendemos nuestro negocio.

Con respecto a la calidad en los servicios de información, De Andrés (2008), establece que ésta puede medirse bajo cinco dimensiones (Figura 4).

Figura 4

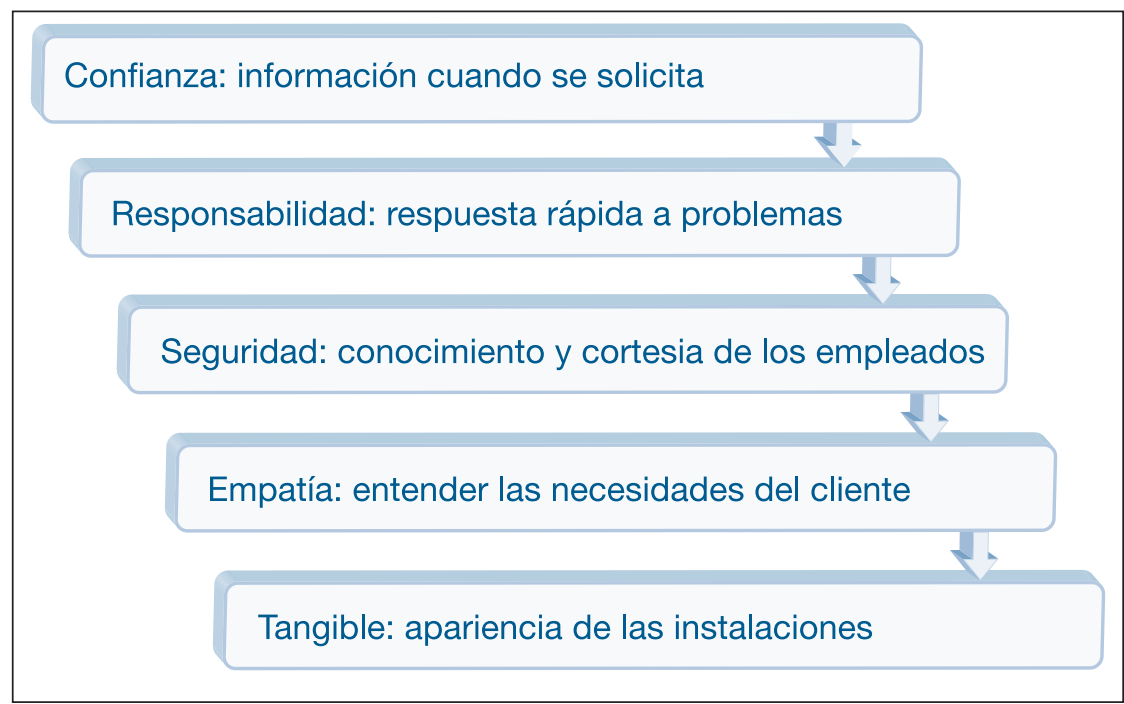

El conjunto de estas dimensiones es el principal componente para que un usuario califique si un servicio tiene calidad o no. 


\section{LEALTAD Y RETENCIÓN DE LOS CLIENTES}

La lealtad del cliente es el profundo compromiso que tiene una persona por volver a comprar, o bien, utilizar un producto o servicio en el futuro, a pesar de que hay otros proveedores con quienes puede encontrar productos similares.

Hoffman (2011) la define como el apego emocional que un cliente le tiene a la empresa que le brinda un servicio.

Sea compromiso o apego, lo cierto es que conservar a los clientes en mercados cada vez más competidos y dinámicos es un logro que refleja el compromiso que tiene la institución por hacer bien las cosas.

La creciente oferta de opciones informativas hace que muchos usuarios de bibliotecas deserten fácilmente hacia otros proveedores o fuentes. De acuerdo con el INEGI, hacia el año 2012 el sistema bibliotecario nacional registró 59.8 millones de consultas a través de 13,308 bibliotecas de todo tipo. Si comparamos estos datos con los registrados en el año 1995, encontramos que el número de consultas decrecieron ya que ese año se registraron 116.3 millones de consultas. Esto significa que, en 17 años, las consultas a bibliotecas mexicanas decrecieron un 48.6\%, 56.5 millones de consultas menos; lo más curioso es que hay 3,468 bibliotecas más que en el año 1995.

Es por esto que el reto actual debe ser el de generar una lealtad de los usuarios hacia nuestras bibliotecas; lealtad que permita crear relaciones de largo plazo, lo cual resulta un factor fundamental para el éxito de nuestras instituciones.

\section{¿Qué es la retención de los clientes?}

Es la actividad que emprende una organización para disminuir o cancelar las pérdidas de clientes. 
Raab (2008) alerta sobre el hecho de que se deben invertir seis veces más recursos en atraer un cliente nuevo que en conservar uno ya existente. Esta es la base de todo éxito comercial y del crecimiento a largo plazo de una organización.

Las razones por las cuales una organización puede retener a un cliente están en función directa del nivel de dependencia que presenta éste con respecto a los servicios que le provee la organización. Esta dependencia puede darse en forma más o menos pronunciada o de forma sutil.

Hay razones de tipo situacional, como por ejemplo la ubicación de la biblioteca, donde el beneficio principal es que ésta se encuentre dentro del área física de estudio, trabajo o esparcimiento del usuario. La comodidad de tenerla cerca puede ser muy fuerte para que la siga utilizando.

También existen razones de tipo psicológico que se basan en los descubrimientos positivos que realiza el cliente sobre la calidad del servicio a lo largo del tiempo. Esto implica el desarrollo de lazos de confianza entre la biblioteca y sus clientes.

Finalmente, encontramos razones del tipo económico a través de las cuales el cliente valorará la decisión de consumo bajo la óptica del menor riesgo. Esto es cuando un usuario busca que el esfuerzo invertido en acudir a la biblioteca sea compensado por la calidad de la información obtenida.

\section{Beneficios de la retención de los clientes}

Aunque pueden resultar obvios los beneficios que tiene retener a los clientes, un repaso de los principales se muestra en la Figura 5. 
Figura 5

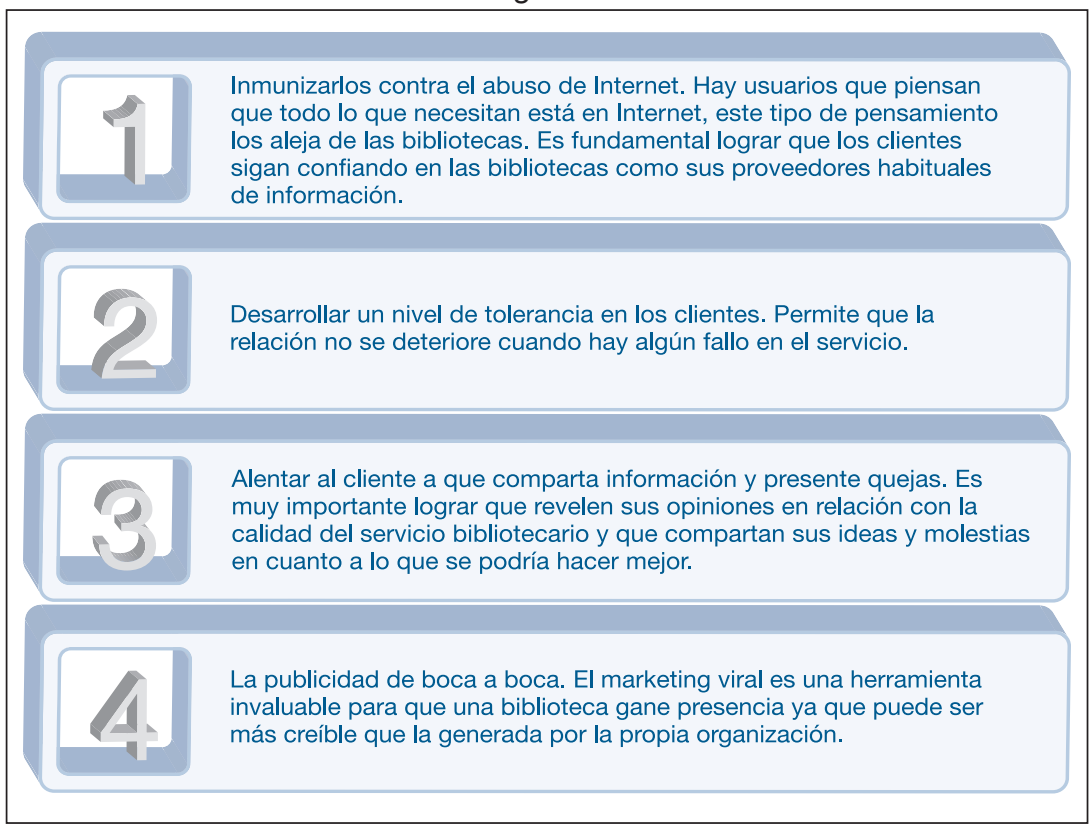

El éxito de toda biblioteca pasa por llevar a cabo estrategias que permitan retener a sus clientes. Cuanto más alto sea el porcentaje de relaciones a largo plazo, la viabilidad de la institución será más alta.

\section{Estrategias para la retención de los clientes}

Una de las condiciones primarias para retener a los clientes es hacer bien las cosas. Philip Kotler (2004) lo dice de esta forma: "Aunque una compañía tenga buena calidad y buen servicio, no necesariamente gana. Eso es lo mínimo que se espera de ella."

Por lo tanto, el establecimiento de un sistema de aseguramiento de la calidad es la primera estrategia que una biblioteca debe poner en marcha. Estos sistemas facilitan la 
identificación de las tareas fundamentales y permiten documentar las experiencias, pero sobre todo brindan elementos para mejorar los procesos y lograr así la satisfacción del cliente a través de servicios confiables a lo largo del tiempo.

Otra estrategia importante puede ser la integración del cliente en el diseño de nuevos servicios. Desarrollar conjuntamente un servicio genera un sentido de pertenencia a través de una conexión emocional y garantiza en gran medida que se cubran las expectativas de los clientes.

Un sistema de gestión de quejas eficiente es una tercera vía a través de la cual se busca la retención de los clientes. Bigné (2010) señala que, muchas veces, el cliente decide abandonar al proveedor no por el fallo en el servicio sino por una respuesta inadecuada de la empresa ante el mismo.

Desde el punto de vista gerencial y de restitución de servicio, es interesante conocer (y predecir) posibles patrones de comportamiento en función de la emoción predominante (enfado o. arrepentimiento) que un consumidor ha sentido durante la experiencia insatisfactoria.

Un cliente enfadado se queja formalmente, pide la devolución de su dinero o acude a terceros actores para resolver el problema. Con su comportamiento genera situaciones delicadas y de tensión en la empresa. Sin embargo, proporciona información muy valiosa que, bien gestionada, da la oportunidad de corregir el problema y evitar que se presente en el futuro. Por otro lado, el consumidor arrepentido es una amenaza para la empresa ya que no se queja, no comunica su insatisfacción, no regresa y habla mal de la empresa.

Un cliente que se queja lo hace con la esperanza de resolver el problema que ha surgido y que normalmente tiene que ver con la decepción de las expectativas que se han experimentado respecto a un producto o servicio. 
Una queja no es una perturbación al trabajo diario. Desestimarlas o atenderlas de mala gana es la receta perfecta para perder clientes. Si bien atender inconformidades no es una tarea agradable, sí es una valiosa oportunidad para mejorar.

Es muy importante instruir al personal sobre lo que deben hacer cuando un cliente reclama. Lo primero es que no tomen las quejas como ataques personales ya que de hacerlo así asumirán posiciones defensivas. Segundo, que no relacionen éstas con regaños o represalias por parte del supervisor pues, de lo contrario, serán los primeros en ocultar las diferencias con el cliente.

Cualquier organización que no lleva a cabo una evaluación del porqué, sus clientes están optando por desertar e irse con otros proveedores, y corre el riesgo de que la tasa de abandono sea tal que se haga inviable su permanencia.

Finalmente, el uso intensivo de las redes sociales, como se verá en el cuarto capítulo de este libro, es actualmente una estrategia fundamental para estar en contacto y retener a nuestros clientes

\section{Hacia una cultura de cero deserción}

Wright (2010) define a la deserción como el cambio que hace un cliente al escoger una marca distinta a la que habitualmente compra durante dos o más períodos consecutivos. En el caso de una biblioteca significaría que, ante la necesidad de obtener información, un usuario dejara de acudir a su biblioteca y prefiriera encontrar la información en otro lado, y esto se repitiera dos o más veces.

Desde los años noventa, el concepto de cero deserción de clientes en las organizaciones de servicios ha estado presente en la literatura especializada. Reichhels (1990) indica- 
ba que si bien no es posible eliminar del todo la deserción, sí es posible gestionarla con miras a disminuirla.

Conocer a nuestros clientes y sus patrones de consumo es el primer requisito. La tasa de deserción es medible y debemos de ser capaces de conocer este indicador.

Enfrentar el fenómeno de la deserción implica un fuerte compromiso de toda la organización. En ocasiones se hace necesario revisar la misión y enfatizar la importancia que tiene la satisfacción de los usuarios. A continuación hay que socializarla entre todos los integrantes de la institución, explicándola y asegurándonos que ha sido comprendida. Mostrar las tasas de deserción y sus posibles consecuencias puede ayudar mucho a que todos entiendan el valor de un cliente.

Descubrir por qué los desertores se van es una segunda fuente de información valiosa para hacer ajustes y proponer mejoras. Por ejemplo, si somos capaces de demostrar que la tasa de deserción está correlacionada con las condiciones de las instalaciones, podemos proponer un plan general de remodelación.

A este respecto Neira (2009) señala que si bien la insatisfacción tras el fallo tiene un efecto importante en la probabilidad de abandono de los clientes, existen otros factores relevantes, tales como la respuesta de la empresa a la queja, las barreras al cambio, la ausencia de alternativas atractivas y la antigüedad de la relación.

A lo largo de este capítulo hemos enfatizado la importancia de entender el comportamiento de nuestros clientes, las cualidades que buscan en un producto o servicio y las expectativas que pueden crear en torno a él. Asimismo, se ha puntualizado la importancia de satisfacer sus necesidades a través de relaciones de largo plazo. Desafortunadamente to- 


\section{davía hay bibliotecas en las cuales predomina un panorama de des-orientación (Figura ๑).}

Figura 6

La eficacia se mide en estadísticas (préstamos, consultas, asistencia, etc.) NO en el grado de satisfacción del cliente

Los procesos y la burocracia están por encima de los problemas y necesidades del cliente

Los servicios de información se ofrecen como paquetes uniformes y no toman en cuenta que hay distintos tipos de usuarios

No hay estrategias efectivas para recopilar, procesar y analizar las sugerencias y quejas de los clientes

Los bibliotecarios debemos de aprender a cambiar de una gestión centrada en el producto a una gestión centrada en el cliente

\section{BIBLIOGRAFÍA}

Bigné, E. R, Currás-Pérez y I. Sánchez-García (2010), "Consecuencias de la insatisfacción del consumidor", en Universia Business Review, cuarto trimestre, núm. 28, pp. 78-101.

De Andrés, J. (2009), Marketing en empresas de servicios, México, Alfaomega. 
Farris, P., et al. (2010), Marketing Metrics: The Definitive Guide to Measuring Marketing Performance. Upper Saddle River, New Jersey, Pearson Education, Inc.

Hoffman, K. (2011), Marketing de servicios: conceptos, estrategias y casos, México, Cengage Learning.

INEGI (2013), Anuario Estadístico de los Estados Unidos Mexicanos, INEGI.

Kotler, P. (2004), Las preguntas más frecuentes sobre marketing, México, Norma.

Noel, H. (2009), Consumer Behaviour, Lausanne, AVA Academia.

Martin, W. B. (2009), Quality Customer Service: Satisfy Customers-it's Everybody's Job, Rochester, N.Y., Axzo Press.

Neira, C., Casielles, R. y Argüelles, V. (2009), "Comportamiento de abandono de la relación de un cliente con la empresa en un contexto de fallo y recuperación del servicio", en Cuadernos de Economía y Dirección De La Empresa (CEDE) (Asociación Científica de Economía y Dirección de la Empresa (ACEDE), núm. 40, pp. 143-169.

Raab, G. (2008), Customer Relationship Management: A Global Perspective, Aldershot, Hampshire, Gower.

Reichheld, F. F., y Sasser Jr., W. (1990), "Zero Defections: Quality Comes to Services”, en Harvard Business Review, vol. 68, núm. 5, pp. 105-111.

Solomon, M (2006), Consumer Behaviour: A European Perspective, 3rd ed., Harlow, Prentice Hall.

Wright, M., y Riebe, E. (2010), "Double Jeopardy in Brand Defection", en European Journal of Marketing, vol. 44, núm. 6, pp. 860-873. 


\title{
Investigación de mercados en las unidades de información
}

\author{
CARlos Curiel Rivera \\ Secretaría Técnica del Gabinete \\ Oficina de la Presidencia
}

\section{INTRODUCCIÓN}

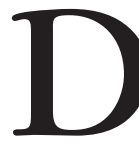

entro de un plan de mercadotecnia en cualquier entidad pública o privada, la investigación de mercados es una fase muy importante que debe llevarse a cabo, ya que a través de ese estudio se podrán conocer e identificar las necesidades, gustos y preferencias del consumidor.

La investigación de mercados es el proceso que se debe seguir y aplicar, con el objetivo de buscar información sobre el comportamiento humano ante cierta situación de consumo.

Este proceso debe incluir estudios de opinión y se aplica a través de la recopilación e interpretación de datos sobre individuos u organizaciones, utilizando métodos y técnicas estadísticas de las ciencias sociales.

Stevens (1997) describe la investigación de mercados "como el procedimiento y las técnicas involucradas en el diseño, recolección de datos, análisis y presentación de la 
información usada en la toma de decisiones de mercadotecnia" y agrega que "conducir una investigación de mercados es un método importante para determinar qué es lo que los consumidores del mercado meta hacen, piensan y dicen."

Es recomendable dar seguimiento y lograr que el alcance de un proyecto o estudio de investigación de mercado cubra todo el ciclo vital de un producto o servicio, desde su introducción al mercado, hasta pasar por la fase de maduración y la forma en que éste se relaciona con el consumidor.

El objetivo de dicho seguimiento en el estudio se resume en las siguientes cuatro palabras "para tomar mejores decisiones", ya que, de lo contrario, sería como navegar sin brújula y la probabilidad de alcanzar el éxito no podría asegurarse, con lo cual se incrementarían los costos que esto implica, tanto en dinero como en tiempo.

Como bien dice Diana Caballero (2009) "hacer investigación de mercados es recomendable por cuatro sencillas razones:"

- Reduce riesgos.

- Descubre oportunidades.

- Mejora los resultados.

- Maximiza la rentabilidad de las inversiones.

Cabe aclarar que las ventajas que representa la investigación de mercados, junto con la elaboración del análisis FODA, nos ayudarán al establecimiento de un buen plan de mejora continua para nuestra biblioteca. 
Naresh K. Malhotra (1999) propone un modelo con seis pasos a seguir para la elaboración de un estudio de investigación de mercados (Figura 1).

Figura 1

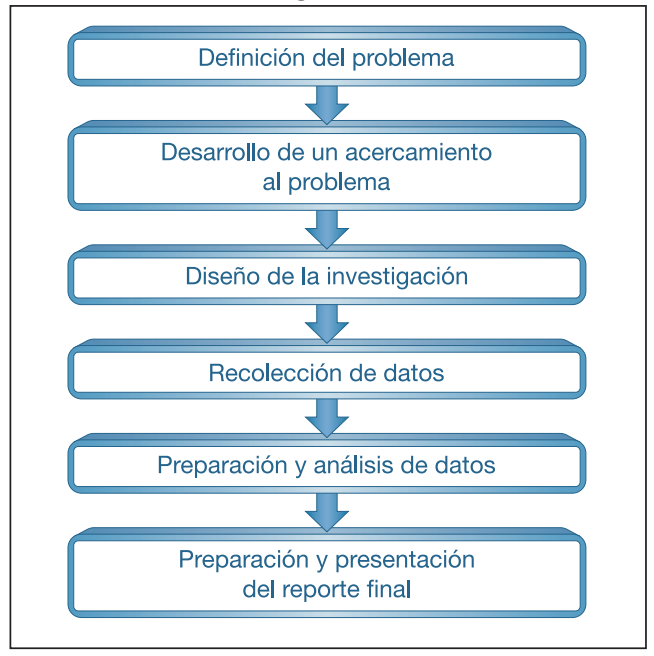

Es importante y recomendable crear un marco de trabajo que sirva como guía al proyecto de investigación de mercado, ya que en éste se detallan los procedimientos que se necesitan para la recopilación y obtención de datos, lo cual permite estructurar y resolver los problemas que surjan durante la investigación para facilitar, en buena medida, el desarrollo del estudio en cuestión.

El diseño de una investigación de mercados puede incluir las siguientes categorías:

- Investigación exploratoria.

- Investigación conclusiva.

- Investigación descriptiva.

- Investigación causal.

- Diseño transaccional. 
- Diseño longitudinal.

- Diseño transaccional único.

- Diseño multitransaccional.

\section{INVESTIGACIÓN DE MERCADOS}

\section{POR TIPO DE FUENTE DE INFORMACIÓN}

Una biblioteca puede distinguirse tanto por la calidad y cantidad de los materiales que constituyen su acervo, así como por la calidad y cantidad de los servicios que ofrece a sus usuarios; la combinación acertada de estos dos factores es lo que otorgará a la unidad de información el sentido y su razón de ser en la sociedad.

Dentro de los servicios que se ofrecen, pueden identificarse dos niveles:

1) Servicios básicos, como: lectura en sala, préstamo de materiales, servicio de consulta, etcétera.

2) Servicios de valor agregado, como: diseminación selectiva de información, elaboración de bibliografías, asesoría personalizada, etcétera.

La aplicación de un estudio de investigación de mercados bien puede ayudar al diseño de estrategias y políticas que coadyuven a alcanzar las metas y logros deseados por las unidades de información.

Existen distintos criterios de clasificación dentro de la investigación de mercados; al respecto, las categorías más recurrentes son aquellas que observan el tipo de fuente de información. Como apoyo en la toma de decisiones dentro de una organización, es común que éstas utilicen la información interna que generan ellas mismas, es decir, los re- 
sultados de su operación, o bien, la información externa, la cual se obtendrá implementando un proceso de investigación de mercados.

En una biblioteca, la información interna es la que normalmente aparece en sus informes y la que contiene cifras relativas al uso de la colección, afluencia de usuarios, consultas atendidas, presupuesto ejercido, adquisiciones, costos operativos, etcétera.

La información externa se genera principalmente de dos vertientes, conocidas como fuentes primarias y fuentes secundarias.

Dentro de una biblioteca es usual tratar de identificar las necesidades de información de sus usuarios, en las que estos ejercicios de investigación generan una serie de temas y descriptores que reflejan los intereses de la comunidad lectora o investigadora.

\section{Investigación de fuentes primarias}

Las fuentes primarias de información son aquellas consideradas como material informativo directo, original y de primera mano respecto al tema investigado y que responden a preguntas sobre su origen:

- ¿De quién se obtiene la información?

- ¿Cómo se obtiene la información?

- ¿Dónde se obtiene la información?

Esta investigación se realiza por medio de la aplicación de encuestas, entrevistas a sujetos, observación directa de hechos, o bien, implementando procesos de experimentación o simulación. 


\section{Investigación de fuentes secundarias}

Las fuentes secundarias de información se refieren a aquellas obtenidas por medio de la consulta de estudios previos que aparecen publicados en libros, bases de datos, catálogos, periódicos u otros medios, omitiendo la realización de un trabajo de campo.

Este tipo de fuentes de información tiene ventajas y desventajas respecto a otras ya que, si bien son más accesibles por su costo económico-temporal, pueden presentar el inconveniente de su disponibilidad, el cual puede ser difícil, restringido, o bien, estar desactualizado o diferir en sus resultados con el propósito de la pesquisa.

\section{INVESTIGACIÓN DOCUMENTAL}

Las fuentes documentales son conocidas también como fuentes secundarias; sin embargo, pueden diferir en su enfoque de mercado. La información contenida en éstas es de un origen completamente externo al entorno de aplicación del estudio, y es recomendable su utilización en el arranque del mismo, enfocándose en un tema particular, cuando los tiempos lo permiten y las preguntas planteadas al principio del estudio pueden ser respondidas por este medio.

En ocasiones la investigación documental es suficiente para cubrir el propósito del estudio que, aunado a su bajo costo, puede plantear el contexto para la realización de investigaciones de mercado posteriores.

Es importante no confundir la consulta documental con la búsqueda de información retrospectiva o histórica, ya que no debe soslayarse la información del día a día que se genera en medios de comunicación impresos y digitales. 
Para las unidades de información, no es suficiente con tener y conocer el perfil de necesidades informativas de sus usuarios; es necesario también conocer la relevancia de dicha información y la forma en que ésta se utiliza.

Como bien señala Miyagi (2001), "si la biblioteca recoge los aprendizajes del comportamiento del consumidor, una combinación de marketing y psicología, tendrá la posibilidad de conocer las motivaciones de sus clientes, sus preferencias, lo que le permitirá desarrollar productos con mayores beneficios deseados".

INVESTIGACIÓN DE MERCADOS POR LA METODOLOGÍA USADA EN LA RECOLECCIÓN DE DATOS

Existen dos diferentes modelos o métodos propuestos para desarrollar una efectiva investigación mercadológica, los cuales son utilizadas indistintamente para la recolección y análisis de datos: la investigación cualitativa y la investigación cuantitativa.

\section{Investigación cualitativa}

La investigación cualitativa consiste en la utilización de técnicas exploratorias como sesiones de grupo (focus group), la observación o la entrevista, siempre en muestras pequeñas, que busca una profundidad en la investigación, evitando la cuantificación.

La investigación cualitativa realiza un registro narrativo del fenómeno estudiado y a diferencia de los métodos cuantitativos, que enfocan su estudio a la asociación o relación que existe entre variables cuantificables, en ésta, dicha relación se realiza en contextos estructurados y situacionales. 
Como mencionan Pita y Pértegas (2002), "la investigación cualitativa trata de identificar la naturaleza profunda de las realidades, su sistema de relaciones, su estructura dinámica”.

Esta técnica empleada en la investigación de mercados se desarrolla a partir del estudio de las ciencias del comportamiento, en un intento por conocer mejor al consumidor $y$ saber no sólo qué elige la gente, sino por qué lo elige.

El empleo de técnicas y teorías provenientes de la sociología, de la antropología y, principalmente, de la psicología, han trascendido en los estudios de mercado y ahora éstos no solo se conforman con conocer las motivaciones del consumidor, sino que han profundizado hasta conocer y comprender sus conductas, es decir, saben lo que el cliente siente, sueña, piensa, anhela y lo que finalmente hace.

Ya no sólo basta con aplicar técnicas de observación; ahora se debe profundizar más, escuchando e intuyendo los deseos del cliente, penetrar en su mente y en su espíritu con el fin de comprender las causas que lo motivan a desear o adquirir un bien y luego entender los procesos posteriores a esta decisión.

Existen en los estudios cualitativos cuatro grandes propósitos de información:

1) Estudios fenomenológicos o descriptivos: aquellos que tratan de entender la experiencia cotidiana y el comportamiento del consumidor.

2) Estudios exploratorios: que tienen la intención de encontrar las causas y razones que llevan a un consumidor a actuar como lo hace, es decir, tratan de entender su comportamiento.

3) Estudios de exploración creativa: modalidad que se utiliza con el fin de estimular procesos creativos, de generación de ideas que sirvan para enriquecer 
las estrategias mercadológicas, como puede ser un cambio de estrategia, el cambio de logotipo de algún producto, el rediseño de alguna campaña, entre otros. Es recomendable aplicar aquí las modalidades de lluvia de ideas y sesión de grupo, reuniendo a clientes y a consumidores.

4) Evaluaciones: su utilización es esencial para comprender y perfeccionar las ideas que se están desarrollando en cualquier etapa de la investigación, que puede ser sobre el proceso de la misma, el producto o la publicidad.

\section{Investigación cuantitativa}

La investigación cuantitativa consiste en la utilización de datos medibles y la correlación existente entre distintas variables cuantificables, tratando de explicar en forma objetiva el porqué de un comportamiento determinado.

Su objetivo es obtener datos medibles, adquiridos a partir de una muestra controlada y estudiada, para analizarlos estadísticamente y realizar proyecciones sobre una población total; esta metodología es utilizada principalmente en la elaboración de estudios de mercado, generalmente a través de la aplicación de encuestas, por medio de cuestionarios estandarizados que, una vez analizados, entregan resultados sobre los diferentes comportamientos, afinidades y diferencias que pueden existir en una población respecto a una marca o producto.

Una variante en la aplicación de esta técnica es la de la observación dirigida, la cual debe registrar y cuantificar las conductas del cliente o consumidor, prescindiendo del uso de cuestionarios. 
Existen diferencias entre ambos métodos, lo cual se ve reflejado en las ventajas y desventajas que muestran estas metodologías y que se presentan en la Tabla 1.

Tabla 1

Diferencias de los métodos cualitativo y cuantitativo

\begin{tabular}{|c|c|}
\hline Método cualitativo & Método cuantitativo \\
\hline Mayor profundidad en la información & $\begin{array}{l}\text { Posibilidad de realizar y comparar } \\
\text { mediciones }\end{array}$ \\
\hline $\begin{array}{l}\text { Los resultados son individuales } \\
\text { y no permiten su generalización }\end{array}$ & $\begin{array}{l}\text { Proyección generalizada de los resultados } \\
\text { a toda la población }\end{array}$ \\
\hline $\begin{array}{c}\text { Comunicación directa } \\
\text { con el entrevistado }\end{array}$ & Poca interacción con los entrevistados \\
\hline Perspectiva holística & Perspectiva particular \\
\hline Estudios dinámicos & Estudios estáticos \\
\hline Énfasis en el proceso & Énfasis en el resultado \\
\hline $\begin{array}{c}\text { Experiencia y conocimiento } \\
\text { en la recolección de información }\end{array}$ & $\begin{array}{l}\text { Análisis de calidad en la interpretación } \\
\text { de los datos }\end{array}$ \\
\hline Alto costo por caso & Alto costo por proyecto \\
\hline Resultados individuales & Resultados generalizados \\
\hline
\end{tabular}

En el caso de las bibliotecas se pueden utilizar cualesquiera de los dos métodos propuestos, siempre sin perder el objetivo del estudio y en función del tamaño de la institución y la densidad poblacional a la que atiende o está dirigida.

Una ventaja dentro de las unidades de información es que éstas cuentan con un público cautivo y una afluencia constante de usuarios; sin embargo, no se debe olvidar al resto de la población. Es altamente recomendable traspasar las puertas y paredes que resguardan los acervos e investigar qué información y servicios demanda la población que 
no utiliza la biblioteca, además de conocer más y de mejor manera a los usuarios frecuentes y así poder ofrecer acervos y servicios de mejor calidad.

\section{INVESTIGACIÓN DE MERCADOS}

POR LA TEMPORALIDAD DE LA INVESTIGACIÓN

La investigación de mercados en sus estudios sobre demanda presenta dos diferentes fases que se determinan en función de su temporalidad y el seguimiento que se da a la investigación, para distinguir así los estudios que se realzan en una sola ocasión, frente a los estudios que se realizan de manera periódica y que se identifican como:

- Estudios individuales (one-shot).

- Estudios continuos (trackings).

\section{Estudios Individuales (one-shot)}

Este tipo de estudio es aquel que se aplica de forma individual, en una sola ocasión y que resulta suficiente para resolver la interrogante planteada; puede ser un estudio de tipo estacional y no tiene un seguimiento cíclico.

Para medir la eficiencia de la biblioteca, se puede aplicar una entrevista personal con el usuario, o bien, a través de un focus group, dentro del cual se puede conocer y, en su caso, resolver con una breve y única sesión el sentir del usuario hacia la unidad de información, realizando una o varias preguntas muy concretas sobre un tema en particular; por ejemplo: colecciones, suscripciones, servicios, horarios, etcétera. 


\section{Estudios continuos (trackings)}

Se refiere a los estudios que se aplican y permanecen durante largos periodos de tiempo, repitiéndose de manera cíclica, conservando o reproduciéndose siempre bajo las mismas condiciones durante diversos periodos de tiempo (cada mes, cada año o en los periodos requeridos), para que puedan ser comparables y sean susceptibles de observar cambios, así como tendencias.

Un ejemplo dentro de la biblioteca se presenta cuando se quiere conocer si un servicio determinado está funcionando de manera eficiente; entonces será necesario aplicar un estudio individual, usuario por usuario, para evaluar el cambio o permanencia del mismo; asimismo, cuando se pretende conocer la percepción que los usuarios tienes sobre la misma unidad de información, es recomendable implementar una evaluación permanente y continua, la cual, con el paso del tiempo, permitirá tener una visión de las fallas y aciertos que tiene a través del tiempo, partiendo de la premisa de que toda organización puede y debe ser comparada con otras similares (benchmarking), pero sobre todo contra sí misma.

\section{OTROS TIPOS DE INVESTIGACIÓN DE MERCADOS}

Existen otros sistemas para implementar una investigación de mercados, los cuales pueden ser efectivos en diferentes contextos.

\section{Datamining}

El datamining o minería de datos es el proceso por el cual se puede descubrir, extraer y almacenar la información re- 
levante de una base de datos, por medio de un software de búsqueda que rastrea e identifica patrones, así como relaciones, tendencias, desviaciones y otros indicadores que, dentro del aparente caos en que se presentan, tienen una explicación lógica, cuyo valor es aprovechado para que el director de una organización tenga un mejor y más profundo conocimiento del comportamiento de sus clientes, a través de un sistema conocido como Sistema de Apoyo a la Toma de Decisiones.

Este sistema de análisis de datos se ha popularizado, primeramente por el abaratamiento y popularidad de las computadoras, los discos duros y las comunicaciones; después, porque las instituciones y empresas privadas generan, respaldan y conservan un gran volumen de información en estos medios.

Se ha descubierto que esta información, la cual permanece en bases de datos conocidas como bases operacionales, es un reflejo fiel de la operación cotidiana de la organización y es generadora a su vez de información relevante, que puede resultar estratégica en la toma de decisiones.

Los grandes almacenes o colecciones de datos tienes dos principales aplicaciones y usos:

- El Procesamiento de Transacciones en Línea (OLTP, por sus siglas en inglés).

- El Procesamiento Analítico en Línea (OLAP, por sus siglas en inglés).

El software que lleva a cabo la minería de datos utiliza diferentes técnicas y algoritmos como son las de:

- Umbrales.

- Tendencias. 
- Franjas de normalidad.

- Comportamiento errático.

- Máximos.

- Patrones frecuentes.

- Reglas de asociación.

- Cúmulos.

La información, una vez compilada y transformada, deberá ser analizada para su interpretación y evaluación, lo que generará nuevos conocimientos que han de servir en el proceso de toma de decisiones.

\section{Geomarketing}

Latour y Floch (2001) definen el geomarketing como "un sistema integrado por datos, programas informáticos de tratamiento, métodos estadísticos y representaciones gráficas destinadas a producir una información útil para la toma de decisiones, a través de instrumentos que combinan cartografía digital, gráficos y tablas".

A través de esta técnica, se analiza la realidad económica y social de los individuos (clientes) desde un punto de vista geográfico, es decir, se analiza al consumidor en relación a la zona donde habita, con la finalidad de crear patrones de consumo y comportamiento, lo cual servirá para ofrecer y mercadear los productos adecuados a su realidad socioeconómica.

Esta disciplina es creada a partir de los procesos de cambio generados por la globalización y como una respuesta de las empresas ante los acelerados procesos de cambio y para la solución de problemas en períodos cada vez más cortos, pasando, como dice Taketa (1993), "de una planificación estratégica a un pensamiento estratégico". 
La necesidad de tomar conciencia del entorno ha generado la creación de nuevas alternativas para enfrentar los problemas y se ha comprendido que el conocimiento geográfico es una herramienta importante para afrontar esta nueva realidad.

\section{Semiótica}

La semiótica es, en palabras de Ferdinand de Saussure (2010), "la ciencia que estudia la vida de los signos en el seno de la vida social", es decir, esta disciplina intenta darnos una explicación de cómo el ser humano se relaciona y conoce su mundo circundante, cómo lo interpreta, genera conocimiento en torno a éste y cómo lo transmite.

Esta área del conocimiento se ha incluido dentro de la investigación de mercados, para tratar de descubrir los pensamientos inconscientes que llevan a un consumidor a tomar ciertas decisiones o presentar diferentes conductas que inciden en la elección de determinado producto o servicio.

Estos estudios no incluyen por lo general investigación de campo y ponen énfasis en analizar los contextos culturales y los códigos de comunicación que emplea un grupo social, como puede ser el uso de algún color o cierta tipografía que transmite mensajes empáticos hacia los clientes.

\section{Neuromarketing}

El neuromarketing se enfoca en técnicas que buscan conocer las reacciones que provocan ciertos estímulos en los consumidores y, para esto, se auxilian de técnicas procedentes de la neurociencia, o bien, de otras ramas de la medicina, como la fisiología, la endocrinología o la cardiología. 
Kevin Randall (2009) lo define como "la práctica de usar tecnología para medir la actividad cerebral en los consumidores para utilizar esa información en el desarrollo de productos y comunicaciones". A través de esta nueva técnica, se pretende conocer y medir las respuestas inconscientes del consumidor, registrando sus reacciones neuronales o fisiológicas ante estímulos publicitarios que actúan en el subconsciente y no son detectables por medio de los métodos tradicionales de investigación.

Las técnicas utilizadas son, entre otras: la Encefalografía (EEG), la Resonancia Magnética Funcional (FMR), el Seguimiento Ocular (Eye Tracking) y la Medición del Ritmo Cardiaco.

Esta novedosa técnica enfrenta todavía retos, como su costo elevado, las consideraciones éticas, la ausencia de una estandarización de resultados y la difícil comunicación que existe entre científicos y mercadólogos; sin embargo, ha tenido logros, sobre todo en áreas de predicción, para saber qué anuncios televisivos pueden tener mayor impacto o la viralidad que una campaña de mercadotecnia puede producir en la red si se proyecta dentro de eventos masivos, como el Super Bowl.

\section{LibQual}

Como ya se mencionó, existe en la mercadotecnia, en particular entre los consumidores de información, un factor muy importante que se vincula estrechamente con la calidad en el servicio. Se trata de la satisfacción del cliente; este factor, para el caso de las bibliotecas, se puede medir directamente y con precisión a través del sistema estandarizado LibQual, que a continuación se describe. 
LibQual es una encuesta universal, estandarizada, validada y aplicada en más de 1,000 bibliotecas en el mundo, que sirve para identificar las áreas de servicio que deben ser mejoradas en una biblioteca o centro de información.

Fue en 1999 cuando dos funcionarios de la biblioteca de la Universidad de Texas A\&M, FreadHeath y Colleen Cook, utilizando un protocolo desarrollado por la misma universidad para el sector empresarial y de nombre ServQual, procesaron las muestras recogidas sobre la percepción que los usuarios tenían respecto a la calidad en el servicio de la biblioteca.

Ambos observaron que el desarrollo de distintas variables, como la de colecciones, se estaban limitando por la calidad de los servicios; en especial, los de tipo digital que se brindaban a través de la Web y que resultaban cada vez más omnipresentes.

En el mes de enero del año 2000, la American Library Association (ALA) realizó una de sus reuniones anuales en la ciudad de San Antonio, donde fue presentado este nuevo producto con su nombre actual: LibQual, que inmediatamente fue aceptado y adoptado por la comunidad bibliotecaria de los Estados Unidos.

El modelo propone la realización de una encuesta en línea (online), basada en 22 preguntas que vienen a proporcionar datos cuantitativos, complementándose con cajas abiertas para verter comentarios libres que refuerzan las respuestas con información de tipo cualitativo.

Las 22 preguntas se agrupan en tres grandes temas:

1. Valor afectivo del servicio $=$

2. La biblioteca como espacio $=$

3. Control de la información $=$
9 preguntas.

5 preguntas.

8 preguntas. 
La herramienta identifica tres niveles de servicio, y cada pregunta debe ser contestada en estos mismos tres niveles identificados como:

1. Nivel de Servicio Mínimo (vM), que es el valor que queda por debajo del nivel de tolerancia del usuario.

2. Nivel de Servicio Observado (vo), que es el valor que el usuario percibe al momento de responder la pregunta.

3. Nivel de Servicio Deseado (VD), que es el valor que el usuario esperaría con respecto al servicio que está evaluando.

Se asume que la Calidad de la Biblioteca es la combinación y suma de estos tres niveles, que se agrupan a su vez en tres dimensiones (Figura 2).

Figura 2

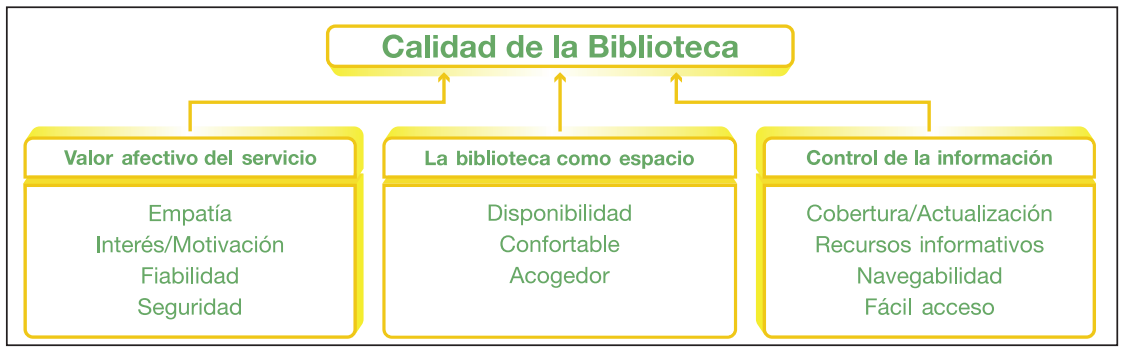

Fuente: Enrique y Javier López-Gijón Herrera-Viedma (2012), Mediciones LibQual: herramienta Secaba.

La ecuación resultante de este ejercicio de medición se compone de la combinación de los datos que resultan de las respuestas de las 22 preguntas, en sus tres niveles de servicio y en sus tres dimensiones, de lo cual se observa una zona de tolerancia y dos indicadores: adecuación y superioridad (Figura 3). 
Figura 3

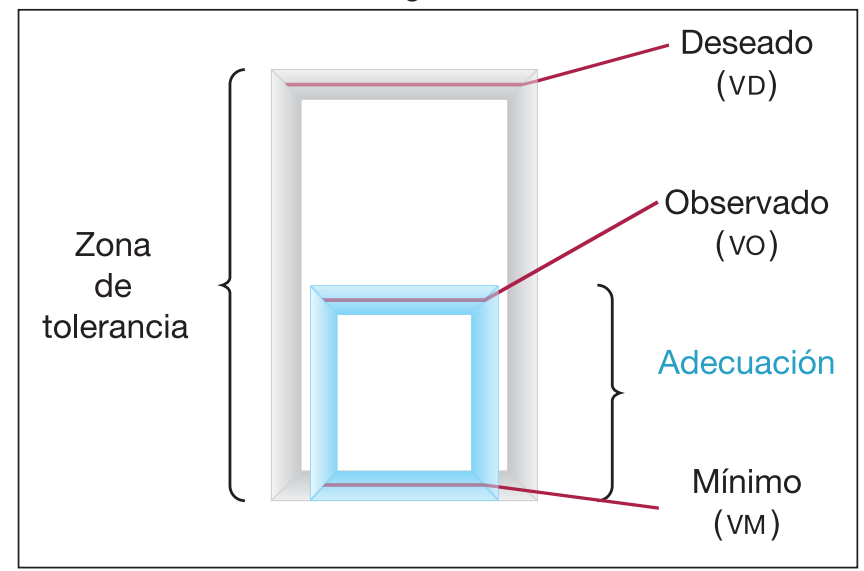

Fuente: Enrique y Javier López-Gijón Herrera-Viedma (2012). Mediciones LibQual: herramienta Secaba.

Una vez realizado el ejercicio y analizados los datos, se procede a integrar un Informe Final de Calidad, que incluye, entre otros: el estudio y la interpretación del mismo, los resultados globales, los resultados por tipo de usuario, conclusiones, recomendaciones y anexos.

Se recomienda que sea un ejercicio periódico que permita obtener resultados concretos, los cuales puedan compararse con los ya obtenidos; asimismo, debe realizarse una buena campaña de promoción entre los usuarios y tener identificada la población a la que se aplicará, en los tiempos estimados para llevar a cabo el estudio.

La encuesta es anónima, se aplica en línea y puede variar en extensión, pero siempre respetando los principios de Calidad de la Biblioteca (véase Cuadro 3), con el fin de poder estandarizar los resultados obtenidos y que sea posible procesarla de manera automatizada. 
Entre las ventajas identificadas al utilizar LibQual, destacan:

- El conocimiento que se tiene de los usuarios, por medio de la percepción que éstos tienen de la biblioteca.

- Mide las expectativas que los usuarios tienen con respecto a la biblioteca.

- Se retroalimenta de la opinión de los usuarios a través del tiempo.

- Identifica las buenas prácticas que la biblioteca posee.

- Se conoce la calidad de la biblioteca, según la satisfacción de los usuarios.

- Permite la adecuación del cuestionario, según las necesidades de cada biblioteca.

- Fomenta las prácticas de Benchmarking, es decir, permite la comparación con otras unidades de información similares.

- Mejora las competencias que los bibliotecarios tienen en el análisis e interpretación de datos.

- Es una herramienta utilizada y probada desde el año 2000 en más de 1,200 bibliotecas alrededor del mundo.

- LibQual se retroalimenta de todos sus usuarios y se encuentra en permanente actualización.

\section{BIBLIOGRAFÍA}

Ángeles Larrieta, María Isabel y Angélica María Santillán Gómez (1998), "Minería de datos: concepto, características, estructura y aplicaciones”, en Contaduría y Administración, núm. 190, pp. 79-84.

Baca Urbina, Gabriel (2000), Evaluación de proyectos, México, McGraw-Hill. 
Caballero, Diana (2009), Plan de vuelo: guía práctica para la investigación de mercados en Latinoamérica, México, Kitelab: Pearson.

Estudio de Mercado (2000) [en línea], http://cortez04.galeon.com/

Herrera-Viedma, Enrique y Javier López-Gijón (2012), "Mediciones LibQual: herramienta Secaba”, en Taller/Seminario. x Conferencia Internacional sobre Bibliotecas Universitarias, México, DF. (5 de noviembre).

Lagos, Jesús (2008), “¿Qué es el Geomarketing?” [en línea], http:// geomarketingspain.blogspot.mx/2008/05/qu-es-el-geomarketing.html

Latour, P y J. Le Floch (2001), Géomárketing: principes, méthodes et applications, Paris, Éditions d'Organisation.

Lerma Kirchner, Alejandro, Sergio Bárcena Juárez y Romeo Vite López (2011), Marketing político, México, Senado de la República, LXI Legislatura, CENGAGE Learning.

"LibQual: charting library service quality" (2013) [en línea], http:// www.libqual.org/home

Malhotra, Naresh K. (2004), Investigación de mercados: un enfoque aplicado, México, Pearson.

Martínez Luna, Gilberto Lorenzo (2011), "Minería de datos: cómo hallar una aguja en un pajar", en Ingenierías, vol, XIV, núm. 53, oct.-dic., pp. 55-63.

Miyagi, Flora (2001), "Marketing en unidades de información y afines: ¿sólo una moda?” en Seminario Virtual de Información para Archivos, Bibliotecas y Museos: marketing de servicios, Lima, Biblios, núm. 10.

"Neuromarketing" (2009), en: Neuromarca: el blog sobre neuromarketing en español [en línea], http://neuromarca.com/neuromarketing/ 
Pita Fernández, S. y S. Pértegas Díaz (2002), "Investigación cuantitativa y cualitativa”, en: Fisterra: atención primaria en la red [en línea], http://www.fisterra.com/mbe/investiga/cuanti_cuali/cuanti_cuali2.pdf

Randall, Kevin (2009). "Neuromarketing Hope and Hype: 5 Brands Conducting Brain Research" [en línea], http://www.fastcompany.com/1357239/neuromarketing-hope-and-hype-5-brandsconducting-brain-research

Saussure, Ferdinand de (2010), Curso de lingüística general, México, Fontamara.

Stevens, Robert E. (2006), Market Opportunity Analysis: Text and Cases, New York, Best Business.

Taketa, R. (1993), "Management and the Geographer: the Relevance of Geography in Strategic Thinking", en The Professional Geographer, vol. 45, núm. 4, pp. 465-470.

Thompson, B. (2007?), “The Origins/Birth of LibQual” [en línea], http://people.cehd.tamu.edu/ bthompson/libbirth.htm 
Las redes sociales en las unidades de información

\author{
JAVIER VELÁZQUEZ GARCÍA \\ Embajada de los Estados Unidos \\ Biblioteca Benjamín Franklin
}

\title{
INTRODUCCIÓN
}

ntes de comenzar, algunas precisiones. Todo nuevo
inicio supone, casi siempre, una preparación o pla-
neación previa antes de comenzar a recorrer el camino que viene por delante. El tema que ahora nos ocupa no podría ser la excepción. Es ideal, entonces, que comencemos la lectura de este capítulo haciendo una revisión de dos particularidades que requieren captar nuestra atención, con el propósito de comprender cabalmente el uso y la aplicación de tecnologías Web 2.0 en ambientes donde la información es la herramienta de trabajo fundamental.

¿REDES SOCIALES (SOCIAL NETWORKING)

O MEDIOS SOCIALES (SOCIAL MEDIA)?

Es muy probable que el lector haya visto o escuchado en la jerga coloquial o profesional con cierta frecuencia las fra- 
ses redes sociales y medios sociales. Y es muy posible también que se haya hecho la pregunta de si estos conceptos se usan indiscriminadamente, si son sinónimos, o si a cada uno le corresponde una particular definición.

La realidad es que, aun cuando haya personas que prefieran alternar los términos cual si hubiera entre ellos cierta sinonimia, cada uno de ellos tiene sus propias características y, en consecuencia, su propio significado. Sin llevar la precisión y diferenciación a un terreno polémico y dogmático, conviene analizar ambos términos a la luz de las mejores prácticas. Veamos, pues, qué es lo que la literatura dice al respecto.

\section{Redes sociales}

Cuando pensamos en una red la palabra nos remite a una especie de ensamble. Una concatenación de vínculos que une o sirve como puente entre un extremo y otro, entre un punto, sistema, lugar o persona y otro, y su correspondiente antagonista. Red es, pues, una palabra que puede sugerir un entorno social o que tiene una aplicación relativa a la sociedad, aunque, hay que decirlo, no necesariamente ya que existen, en contraparte, otro tipo de redes cuyo enfoque escapa plenamente a lo social, como las redes neuronales o las redes biológicas.

La frase redes sociales, refiriéndonos a entornos donde el Internet es el protagonista, proviene de un encadenamiento de entidades ligadas de forma remota entre sí por medio de la tecnología -computadoras, teléfonos celulares-. El mero hecho de poder enviar y recibir información -conectarseentre un punto (persona, entidad) de la cadena y otro (persona, entidad) convierte, por defecto, a este ensamble en 
social, entendiendo lo social como aquella arena o entorno donde se promueve el interés común y mutuo.

Definitivamente el ser humano, por su naturaleza, es un animal social capaz de crear vínculos ciertamente complejos. Esta aseveración se comprueba fácilmente a través de la extensa demostración de ejemplos que encontramos en el devenir cotidiano: desde la distribución de roles encaminados a un objetivo común, hasta ejercer cierto poder en la conducta de los demás - la moda, las formas y modales sociales, el poder-. Consideremos, en este contexto, el advenimiento del Internet a través de la red Arpanet.

Arpanet es el antecedente de lo que ahora conocemos como Internet; surgió principalmente como un medio que permitió a los científicos resolver dificultades para poder ejecutar programas en computadoras remotas. Todas las tecnologías, nos recuerda Janet Abbate (Abbate, 2000), son un producto de su medio ambiente social; es por ello que no debería sorprendernos cómo el acceso a la tecnología ha provocado que un número cada vez mayor de personas se encuentre hoy en día estableciendo relaciones, interactuando en forma bilateral o en grupo, y comunicándose con diferentes propósitos.

Con el tiempo, la red de redes pasó de un entorno exclusivamente militar al comercial, y de ahí, derivó rápidamente a una masificación y penetración definitiva en la sociedad. Pero, ¿en qué momento lo social se volvió más social? o por decirlo de otra forma, ¿cuándo la sociedad entendió que podría funcionar como tal?

Situamos en los primeros años del siglo XXI el advenimiento de tecnologías -comúnmente conocidas como Web 2.0- que permitieron o posibilitaron un mayor enlace entre aquellas personas que contaban con un dispositivo electrónico -computadora, teléfono celular- el cual les permitía no 
sólo intercambiar mensajes en tiempo real, sino ser actores directos y no meramente receptores. La idea predominante en todo este ejercicio era la conectividad, tal y como lo explica Dan Zarrella en su libro The Social Media Marketing Book.

Las redes sociales, nos explica Zarrella (Zarella, 2010), "fueron concebidas para enfatizar fuertes conexiones entre las personas -personas que se conocen en la vida real, más que conocidos ocasionales en línea”. Aunque esta afirmación pudiera resultar parcialmente cierta, principalmente si consideramos que algunas relaciones se cultivan primero en línea y después en la vida real.

Una red social es un sitio Web que ha sido desarrollado con tecnologías Web 2.0. Recordemos que el Internet ha ido evolucionando en estas dos últimas décadas, y hemos pasado de la Web 1.0 a la Web 2.0, etapa en la cual estamos situados actualmente. El termino Web 2.0 fue acuñado por Darci Dinnuci (Dinnuci, 1999) en su artículo "Fragmented Future", pero popularizado años después por Tim $\mathrm{O}^{\prime}$ Reilly en su artículo "What Is Web 2.0: Design Patterns and Business Models for the Next Generation of Software" (O'Reilly, 2005).

O’Reilly intentó establecer cuáles eran las ideas que definían o implicaban el término Web 2.0; para ello elaboró un listado que, confrontado con las características de la Web 1.0, reveló aquellos conceptos que distinguían o daban una idea de lo que implicaba la Web 2.0 (Tabla 1).

Tabla 1

\begin{tabular}{|cc|}
\hline Web 1.0 & Web 2.0 \\
\hline DoubleClick & Google AdSense \\
\hline Ofoto & Flickr \\
\hline Akamai & BitTorrent \\
\hline Mp3.com & Napster \\
\hline Britannica Online & Wikipedia \\
\hline Personal websites & Blogging \\
\hline
\end{tabular}


Tabla 1 (cont.)

\begin{tabular}{|cc|}
\hline Web 1.0 & Web 2.0 \\
\hline Evite & Upcoming.org and evdb \\
\hline Domain name speculation & Search engine optimization \\
\hline Page views & Cost per click \\
\hline Screen scraping & Web services \\
\hline Publishing & Participation \\
\hline Content management systems & Wikis \\
\hline Directories (taxonomy) & Tagging ("folksonomy") \\
\hline Stickiness syndication & Syndication \\
\hline
\end{tabular}

Fuente: Tom O'Reilly, "What Is Web 2.0: Design Patterns and Business Models for the Next Generation of Software" (2005).

"La segunda generación de la web, esto es, el web 2.0 o el web social, está basado en una conversación de dos vías, interacción, entorno comunitario, contenido generado por el usuario, y relaciones" (Gunelius, 2011). Esto nos lleva a concluir que la Web 2.0 permite crear sitios Web que proporcionan las herramientas básicas para que se generen asociaciones -redes- que promuevan la conectividad social. Las redes sociales permiten, pues, la comunicación e interacción de personas vía Internet.

\section{Medios sociales}

Si bien en la literatura especializada el término medios sociales aparece con definiciones vagas, debemos entender que un medio social es el vehículo o la forma mediante la cual establecemos comunicación con nuestros interlocutores; mientras que las redes sociales son el soporte por el cual establecemos dichas relaciones. Dicho de otra forma, los medios sociales representan los medios o caminos por los cuales se lleva a cabo la función de comunicar. 
Estos medios pueden tener diferente origen y estar destinados a un universo particular: impreso, televisión, radio y, por supuesto, Internet. El diccionario Merriam Webster (2013) señala que un medio social es "una forma de comunicación electrónica (como los sitios web para redes sociales o las páginas de micro relatos -microblogging- a través de los cuales los usuarios crean comunidades en línea para intercambiar información, ideas, mensajes personales y otros contenidos (videos, por ejemplo)."

Estos medios bien podrían ser denominados, si se me permite, medios de comunicación; y cuando menciono la palabra medios, aparece también la palabra mensaje y, de forma automática, evoco las ideas de un hombre que, sin lugar a dudas, fue todo un vanguardista respecto a los temas que ahora nos ocupan: me refiero a Marshall McLuhan.

Si el lector no ha leído al mencionado genio, o si en el devenir de los años ha olvidado sus máximas prácticamente proféticas -el medio es el mensaje, por ejemplo-, a continuación se destaca una muestra que permite corroborar la validez de sus atemporales ideas incrustadas en estos tiempos fértiles en "novedades", y donde todo parece está encaminado al entorno de lo "social".

En una cultura como la nuestra, con una larga tradición de fraccionar y dividir para controlar, puede ser un choque que le recuerden a uno que, operativa y prácticamente, el medio es el mensaje. Esto significa simplemente que las consecuencias individuales y sociales de cualquier medio, es decir, de cualquiera de nuestras extensiones, resultan de la nueva escala que introduce en nuestros asuntos cualquier extensión o tecnología nueva. Así, por ejemplo, con la automatización, es cierto que los nuevos esquemas de asociación humana tienden a eliminar puestos de trabajo. Ése es el resultado negativo. El lado positivo es que la automatización crea funciones para la gente o, lo que es lo mismo, una intensificación de su implicación en su trabajo y asociaciones humanas, que la precedente tecnología mecánica había destruido (McLuhan, 1996). 
McLuhan no se equivoca cuando afirma que las nuevas tecnologías intensifican las asociaciones humanas; no debería sorprendernos, por lo tanto, todo este despliegue aparentemente novedoso que hoy en día está generando esta "nueva" forma de comunicación que ha ido permeando a la sociedad en los últimos años.

Los medios sociales, nos guste o no, queramos o no, han entrado a nuestras vidas y estarán en nuestra cotidianeidad por lo menos durante el futuro inmediato. No se percibe ningún otro rumbo tecnológico que sugiera lo contrario, como tampoco argumentos de peso que nos inhiban a subirnos a este nuevo momentum que vive nuestra civilización. Mal haríamos si cerramos los ojos, pero mucho peor aún resultaría sobrevalorar el fenómeno. Las circunstancias nos obligan, pues, a considerar estas nuevas formas de comunicación con el objetivo final de establecer comunidades eficientemente interconectadas y eficientemente asociativas.

Una vez hechas las precisiones que el tema demanda, procederemos a explorar los beneficios que la Web 2.0 aporta al entorno bibliotecario.

\section{Las redes sociales en bibliotecas y otras unidades de información}

En un mundo donde la tecnología gobierna, los espacios que permanecen intocables son realmente nulos. En esta ola tecnológica masiva sin precedentes, el impacto de la Web 2.0 ha penetrado en la estructuras de prácticamente todos los sectores de la sociedad. Bibliotecas, libros, editoriales, usuarios y lectores no han escapado a este baño de modernidad.

Corriendo detrás de la tecnología, el gremio bibliotecario comenzó apenas hace algunos años a explorar las posi- 
bles aplicaciones e impactos que esta fiebre de la Web 2.0 ofrece. Fue así como en la literatura profesional apareció la palabra Library 2.0 -Biblioteca 2.0-, emulando términos similares utilizados en otras áreas del conocimiento: Health 2.0 -Medicina 2.0-, Politics 2.0 -Política 2.0-, Education 2.0 -Educación 2.0-, etcétera, y cuya denominación tuvo su origen en aquel popularizado por Tom O’Reilly como se mencionó líneas atrás: Web 2.0.

Los primeros visos de la presencia de la Web 2.0 en el mundo bibliotecario se registran en 2005. Ante la avalancha de novedades o posibilidades que la nueva plataforma proponía -Podcast, Blogs, Rss, wikis, entre otras- se hizo necesario y obligatorio introducirse en esta ola tecnológica prometedora y masiva.

En estos primeros intentos por definir la Web 2.0 en las bibliotecas, resultaron evidentes cuatro ideas o características de la nueva tecnología (Levine, 2005).

- Comunicación.

- Conectividad.

- Comunidad.

- Colectividad.

Estas mismas características fueron identificadas de forma similar por Kevin Curran (Curran, 2006) tipificándolas de la siguiente manera:

- Contenido generado por el usuario, en oposición al contenido publicado únicamente por el sitio.

- Trata a los usuarios como si éstos fueran co-desarrolladores del sitio. Cuantas más personas lo utilizan mejor se vuelve. Promueve que el usuario participe a través de comentarios, revisiones, etcétera. 
- Contenido e interfaz altamente personalizable. Permite, por ejemplo, que el usuario diseñe sus propios canales de noticias en su página Web, como en www.netvibes. com.

- La aplicación principal de la página Web corre a través del navegador y el servidor Web, en lugar de en una plataforma de escritorio.

- La incorporación de las tendencias de Internet más populares, como "blogs", "tagging”, "podcasting”, "wikis", el intercambio de contenidos, y el uso de las normas Web, como el lenguaje XHTML y Hojas de Estilo en Cascada (CSS).

- La Integración de tecnologías emergentes Web, como JavaScript asíncrono y XML (AJAX), Really Simple Syndication (RSS) y aplicaciones para programación de interfaces (API).

Como el lector habrá podido deducir, hubo ciertas aplicaciones en ambiente Web 2.0 que rápidamente entraron al escenario; nos referimos al blogging, Rss, podcast, etiquetado (tagging), y algunas otras particularidades, como los mashups y folksonomias (al final de este capítulo el lector podrá encontrar un glosario con los términos más recurrentes del entorno Web 2.0)

El detonante, por darle un nombre a este abrupto (re)surgimiento de aquello que ahora denominamos y se entiende como redes sociales, lo encabezaron sitios como Facebook, Twitter, Youtube y Myspace, plataformas que por su particular facultad de potenciar diferentes formas de comunicarse o conectarse, tuvieron una popular recepción entre la gente que utilizaba el Internet, volviéndose un asunto viral y, si se me permite decirlo, hasta una obligación volverse usuario 
de estas plataformas: si no tienes una cuenta en Facebook o Twitter estás prácticamente fuera de moda.

Con este panorama predominando, los profesionales de la información comenzaron a utilizar diferentes redes sociales con diversos propósitos (Tabla 2).

Tabla 2

\begin{tabular}{|c|c|c|c|}
\hline Nombre & Descripción & $\begin{array}{l}\text { Uso en bibliote- } \\
\text { cas }\end{array}$ & Url \\
\hline Facebook & $\begin{array}{c}\text { Sitio utilizado para } \\
\text { establecer comunica- } \\
\text { ción entre personas y } \\
\text { negocios }\end{array}$ & $\begin{array}{l}\text { Intercambio de cono- } \\
\text { cimiento; difusión }\end{array}$ & http://www.facebook.com \\
\hline Twitter & $\begin{array}{c}\text { Sitio para hacer micro- } \\
\text { blogging }\end{array}$ & $\begin{array}{l}\text { Permite mantener al } \\
\text { usuario y al personal } \\
\text { de la biblioteca estar } \\
\text { al tanto de notifica- } \\
\text { ciones diarias }\end{array}$ & http://www.twitter.com \\
\hline Myspace & & Calendarios noticias & http://www.myspace.com \\
\hline Ning & $\begin{array}{l}\text { Plataforma para crear } \\
\text { redes sociales }\end{array}$ & $\begin{array}{l}\text { Compartir con usua- } \\
\text { rios o colegas }\end{array}$ & http://www.ning.com \\
\hline Blogger & $\begin{array}{l}\text { Sitios para colocar } \\
\text { comentarios }\end{array}$ & $\begin{array}{l}\text { Colocar imágenes, } \\
\text { comentarios, inter- } \\
\text { cambiar temas }\end{array}$ & http://www.blogger.com \\
\hline Wikis & $\begin{array}{l}\text { Colaboración para la } \\
\text { creación de contenidos }\end{array}$ & $\begin{array}{l}\text { Desarrollo de conteni- } \\
\text { dos en la web }\end{array}$ & $\begin{array}{l}\text { http://librarywikis.pbworks. } \\
\text { com/ }\end{array}$ \\
\hline Linkedin & $\begin{array}{l}\text { Red de contactos } \\
\text { profesionales }\end{array}$ & $\begin{array}{l}\text { Intercambio con } \\
\text { especialistas }\end{array}$ & http://www.linkedin.com \\
\hline Youtube & $\begin{array}{l}\text { Comparte material } \\
\text { audiovisual }\end{array}$ & Cursos, talleres & http://www.youtube.com \\
\hline Flickr & $\begin{array}{l}\text { Sitio para compartir } \\
\text { imágenes }\end{array}$ & $\begin{array}{l}\text { Distribuir imágenes } \\
\text { de las colecciones }\end{array}$ & http://www.flickr.com \\
\hline Librarything & $\begin{array}{l}\text { Plataforma para los } \\
\text { fanáticos de libros }\end{array}$ & $\begin{array}{l}\text { Permite catalogar } \\
\text { libros }\end{array}$ & http://www.librarything.com \\
\hline
\end{tabular}

Fuente: Chinwe Nwogo Ezeani, “Using Social Media for Dynamic LibraryService Delivery: The Nigeria Experience", en Library Philosophy and Practice (2012: 1-8). 
Hay algunas características de esta nueva tecnología que se emparentan perfectamente con elementos que forman parte de la naturaleza de las bibliotecas y la misión por la que éstas fueron creadas. Nos referimos fundamentalmente a:

a) Compartir, intercambiar.

b) Comunicar, difundir.

c) Conocer, administrar o hacer llegar el conocimiento.

d) Comunidad, promoción cultural, desarrollo comunitario.

Luego entonces, se preguntará el lector, ¿qué motor puede mover al profesional de la información a considerar algo que las bibliotecas y los bibliotecarios ya venían haciendo? La respuesta podría parecer sencilla pero no lo es, ya que incorpora o acentúa elementos que deben ser sutilmente considerados para lograr que la tecnología juegue a nuestro favor.

Estamos en un punto de inflexión donde el tema no es si entramos o no a este nuevo embate tecnológico, sino cómo obtener los mayores beneficios. El desafío para todos nosotros se origina de la posibilidad de establecer una dialéctica que nos permita ya no sumarnos u oponernos al uso de las tecnologías imperantes, sino, a manera de conveniencia, hacer un uso racional y eficiente de lo que en la actualidad está de moda y predomina: si del cielo te caen limones entonces aprende a preparar limonada. Ir contra el cambio no resulta tan productivo como la habilidad de adaptarse a las nuevas reglas del juego.

Después de todo, la tecnología ha modificado permanentemente para siempre y desde hace varios ayeres -con resultados positivos y otros no tanto- la manera en cómo nos acercamos y manejamos la información y generamos conocimiento. Nos corresponde, por lo tanto, evaluar el uso 
de las nuevas tecnologías (redes sociales), y replantear la relación sociedad-información-biblioteca-persona.

Uno de los aspectos vitales a considerar en el tema de las plataformas Web 2.0 es, sin duda, la conectividad, entendida no como el mero acto de crear un mero enlace físico, sino de extender los alcances que el mismo término implica. Estar en red o estar en-red-ados es, si se me permite, el asunto medular en la integración de redes sociales en bibliotecas y unidades de información.

Estar en red no significa, simbólica o literalmente, estar conectados -relacionados-, así como conectarse no significa, o implica, estar relacionado; desafortunadamente y en virtud a la relativa facilidad con la que se accede a crear y tener una presencia en línea (on-line) es como se fabrica una falsa ilusión de pertenencia; esta situación ha sido diametralmente potenciada con la llegada de telaraña $2.0 \mathrm{o}$ Web 2.0 a nuestro entorno.

Desafortunadamente y puesto que las novedades tecnológicas no esperan ni se detienen, la mayoría de nosotros nos hemos tenido que subir a un tren sin retorno y de futuro incierto. Como estas tecnologías mutan sin previo aviso, no hay un capacitación formal que permita aprender a utilizarlas ni a sondearlas para encontrar sus reales beneficios más allá de la fama que les precede. Se nos ha dicho, o al menos con esa premisa se promueve, que esta fase de la red -por lo menos de la Web- hace posible la comunicación uno a uno y permite la participación activa del individuo mediante la creación y la distribución de contenidos. El concepto como tal no es desdeñable, pero el asunto se nubla cuando descubrimos que hay centenares de sitios y aplicaciones en ambiente red 2.0 (Web 2.0) ¿Cuál utilizamos? ¿Cuál ignoramos? ¿Son fáciles de utilizar y se adecuan a lo que necesito? 
¿O valdría la pena considerar desarrollar mis propias aplicaciones Web 2.0?

Queda claro que la tecnología permite crear recursos físicos -hardware o software- que sirven como puente o vía de enlace, pero las conexiones, o dicho con propiedad, las relaciones y vínculos que se establecen a través de los medios deben ser creados convenientemente por nosotros, privilegiando una verdadera comunicación y fomentando el conocimiento.

Hace algunos meses, en el Congreso Nacional de Bibliotecas en Ciencias de la Salud (5 y 6 de septiembre de 2013), hice algunas precisiones de lo que como profesionales de la información deberíamos considerar al explorar los terrenos de la Web 2.0. A continuación rescato lo mencionado en esa ocasión con la finalidad de que el lector vaya formando su propia opinión y comience a vislumbrar posibles escenarios.

\section{El mundo es plano (y también híbrido)}

Globalización, sociedad de la información, sociedad del conocimiento, son términos que tienen una connotación incluyente y visionaria; sin embargo, estamos obligados a considerar que no todo pasa por esos filtros. Vivimos en un mundo de tecnología digital donde el papel coexiste, los trámites en filas permanecen, e irónicamente, la mayoría de las personas en este planeta carecen de acceso a la tecnología. Habitamos un mundo de realidad y fantasía, de inequidades y oportunidades donde conviven lo nuevo y lo tradicional, lo virtual y lo real, y llevamos una doble vida que coexiste entre el mundo digital y el verdadero. No nos vamos a inundar con datos estadísticos para demostrar que la tecnología aún sigue ausente en el menú de muchos desafortunados; así es que, cuando piensen en la red 2.0, consideren cómo incluir a esa 
parte de la comunidad que carece de conexiones y entramados tecnológicos. Usar tecnología que no es de punta no es un pecado capital si se encuentra la capacidad de innovarla. Habrá que ser creativos para darle una nueva cara a aquello que no es obsoleto, pero que dejó de ser nuevo porque perdió novedad e inmediatez.

\section{Todos en la red: (¿todos con todos o todos contra todos?)}

¿Necesitamos crear redes o necesitamos crear mejores servicios? ¿Se han preguntado qué podría ocurrir si cada persona o grupo fuera capaz de crear su propia red y tener presencia en el ciberespacio? Amén de que sería muy difícil relacionarse con por lo menos un número representativo de ellos, lo realmente complicado para éstos sería lograr captar mi atención. La oferta excesiva de presencias en la red genera una competencia cada vez más difícil y encendida por atraer un mayor tráfico humano a los sitios en la red; la palabra clave, por lo tanto, no es si se debe estar en la red o no, sino atender, capturar, retener y aumentar el número de relaciones establecidas.

\section{La Torre de Babel (y el monstruo de mil cabezas)}

¿Qué lenguaje hablamos los que estamos en la telaraña social (Web 2.0)? Y no me refiero al idioma. Hablo simplemente de comunicación. ¿Entendemos realmente lo que la gente necesita? ¿La escuchamos, o proyectamos en ella nuestras propias necesidades? ¿Somos asertivos y claros, o rellenamos espacios por hábito u obligación? ¿Qué es lo esencial, trascendental en el día a día? ¿Qué clase de información es vital para aquellos con los que me relaciono? ¿Contribuyo 
a la explosión de la (des)información o mis intervenciones son concisas y sustentables?

\section{Construyendo comunidades inteligentes}

Tengo la impresión de que en nuestro entorno las bibliotecas y centros de información han sido creados más por obligación que como el resultado de una necesidad y concatenación de esas estructuras con la sociedad; son un complemento infaltable que todo discurso o proyecto cultural y educativo debe incluir.

Como son entidades artificiales sin peso específico, no encuentran su lugar en una sociedad carente de hábitos por la lectura, habilidades informativas y aprecio al binomio información-conocimiento. Si algo bueno puede emerger de la telaraña social es la posibilidad de dar vuelta a la tuerca para redefinir el rol que las capitales -unidades de información- del conocimiento deben significar para nuestra sociedad. Con la aplicación inteligente de recursos red 2.0 tenemos ahora, más que nunca, la opción de crear comunidades de correspondencia biunívoca e insertarnos en la columna vertebral de estos entornos para provocar los cambios significativos que todos quisiéramos atestiguar en la percepción del colectivo. Esta puede ser una oportunidad única para formar a los nuevos usuarios de la información que actualmente, en su mayoría, son niños y jóvenes.

\section{Necesidades de información vs participación e interac- ción (el usuario manda)}

Hace tiempo los estudios sobre necesidades de información eran un tema recurrente en la literatura bibliotecológica. Tal interés era comprensible porque desconocíamos directa- 
mente las motivaciones de nuestros usuarios y las palancas que activaban su accionar. Hoy, en lugar de preocuparnos sobre las necesidades de información de los individuos, habrá que preguntarnos si somos capaces de escucharlos y de establecer una comunicación uno a uno. El punto de quiebre ahora no es ¿qué quiere la gente?, sino ¿qué es lo que la gente dice, piensa, valora, interpreta o manifiesta? En pocas palabras: ¿qué está haciendo la gente y hacia dónde se está moviendo?

Las nuevas relaciones son lineales y no verticales, y demandan no simplemente interacción, sino un elevado compromiso. Permiten que el usuario te diga qué y cómo lo quiere. Ésta es también otra puerta que la red 2.0 ha dejado abierta y de la cual nos podemos beneficiar como nunca antes.

Por otro lado, y más allá de lo meramente tecnológico, continúa vigente la posibilidad de adoptar y adaptar aquellas técnicas, métodos o procedimientos que tienen su origen en otras disciplinas, pero que encuentran eco en la nuestra. Tal es el caso de la Ley Pareto, el Six Sigma, la reingeniería y, por supuesto, la mercadotecnia.

La mercadotecnia (marketing) ha sido una herramienta que ha despertado buen interés en el gremio bibliotecológico en los últimos treinta años; sin embargo, su uso, en combinación con las redes sociales, vislumbra un mejor panorama para su aplicación en bibliotecas, centros y unidades de información.

Si bien algunas actividades relacionadas con la mercadotecnia han sido realizadas por los profesionales de la información en sus actividades cotidianas -como la promoción y divulgación, primordialmente-, tengo la impresión de que, por lo menos en nuestro entorno, el interés por la mercadotecnia no ha permeado por completo en muchos de nosotros. ¿Por qué habría de interesarme en crear una marca o 
hacer un plan de mercado, cuando los usuarios siempre van a necesitar de una biblioteca?

Este argumento podría ser válido para algunos, sobre todo en entornos de enseñanza-aprendizaje donde el alumno es el que tiene que acudir obligadamente a la montaña, y no la montaña a él. Después de todo, el ciclo escolar siempre es el mismo y se repite año con año y generación con generación, y es el alumno quien debe preocuparse, si quiere tener éxito en su preparación académica, de hacer lo necesario para asegurar tal fin.

El recinto que abastece de información al educando mientras éste cumple su ciclo estudiantil ha estado, está, y permanecerá ahí, más allá del mismo estudiante. La labor de las bibliotecas y entidades de información, por consiguiente, no terminan ni comienzan con el alumnado. Su existencia está obligadamente garantizada prácticamente por decreto: impensable concebir un recinto educativo sin biblioteca, por pequeña, modesta, o utilitaria que pudiera llegar a ser.

Este panorama, sin embargo, no podría ser el mismo en recintos donde la justificación de la existencia de las unidades de información está condicionada por parámetros financiero-utilitarios; es decir, ¿se justifica una inversión de $x$ presupuesto para sostener una biblioteca que tiene $n$ empleados y que genera $y$ resultados?

En países donde las bibliotecas cumplen para la sociedad un rol esencial, pero que están sujetas estrechamente al financiamiento vía recaudación local de impuestos, las restricciones económicas son cada vez mayores para su funcionamiento.

En un artículo publicado por el periódico Huffington Post, en los Estados Unidos, "Why It's Time To Speak Up For Our Libraries" (Losowsky, 2011) se da cuenta de las severos 
cortes financieros que han sufrido las bibliotecas en tiempos recientes:

Al igual que nuestros parques públicos y los museos, las bibliotecas públicas son lugares de reunión libre, no comercial, abiertas para todo el mundo independientemente de sus ingresos. Si la información es poder, entonces las bibliotecas son la esencia de la democracia y la libertad. En estos tiempos de dificultad económica, un gran número de personas las están usando más que nunca, para hacer algo más que exclusivamente sacar libros.

Sin embargo, las bibliotecas públicas de nuestro país parecen estar bajo amenaza por una letanía de recortes, obligados por los comités estatales y locales, recortes que a menudo comenzaron antes de la reciente recesión económica (2008). En una encuesta realizada por la revista Library Journal, el 93\% de las grandes bibliotecas reportó haber despedido personal, haber reducido sus horas de apertura, o ambos. En varios estados, incluyendo Illinois y Michigan, las sucursales de la bibliotecas han cerrado definitivamente sus puertas.

Como si las restricciones económicas no fueran, por sí solas, un reto, habría que considerar el gran desafío al que se enfrentan las bibliotecas frente a la presencia del Internet, los libros electrónicos y otras tecnologías de la información. Con el Internet como sitio dominante para la lectura y la escritura, sobre todo entre los jóvenes, señala un reporte elaborado por Marcia Clemmitt (Clemmitt, 2008):

[...] algunos especialistas predicen que con el tiempo sólo una pequeña "clase lectora" leerá novelas, libros de cierta extensión o revistas serias. La investigación sociológica demuestra que ha habido durante mucho tiempo, una distinción entre la lectura como una práctica donde se lee de todo, y la lectura de literatura seria como una práctica culta o de alta estima practicada por la élite educada, escribieron tres sociólogos de la Universidad de Northwestern. La brecha entre esos dos mundos parece estar ampliándose notablemente. 
Estas reflexiones nos llevan a considerar el adoptar estrategias que nos permitan justificar no únicamente la existencia de las unidades de información y su relación con indicadores costo-beneficio, sino que convendría replantear también la relación usuario-biblioteca-bibliotecario en términos que permitan crear asociaciones más dinámicas que mejoren no solamente la comunicación, sino también la circulación del capital intelectual que posee la biblioteca con la finalidad de ofrecer mejores servicios. Esta estrategia bien podría ser encabezada por el binomio mercadotecniaredes sociales.

\section{MERCADOTECNIA Y REDES SOCIALES}

Existen suficientes argumentos para considerar la aplicación de la mercadotecnia en combinación con las redes sociales, en las tareas de los profesionales de la información; pero, inicialmente, necesitamos replantear ¿qué es la mercadotecnia?, o mejor aún, ¿cómo definimos la mercadotecnia en un lenguaje práctico para los profesionales de la información?

Hay diferentes concepciones que procuran definir el término mercadotecnia, pero por su estrechez con nuestra área, la que se cita a continuación, adaptada para los fines que nos ocupan (Pérez Romero, 2004), resulta la más apropiada para nuestro entorno:

La mercadotecnia social (aplicada a bibliotecas) es el diseño, implementación y control de programas dirigidos a incitar la aceptación de ideas sociales (fomento a la lectura, acudir a la biblioteca, etcétera), mediante la inclusión de factores como la planeación del producto (servicio), precio (acceso), comunicación (difusión), distribución (disemina- 
ción) e investigación de mercados (estudios de usuarios, estudios de información).

En una primera aproximación a esta definición, podemos comentar que la mercadotecnia es el proceso que nos permite, en primera instancia, identificar aquel público al cual pretendemos ofrecer los servicios de nuestra institución; en segundo lugar, nos ayuda a comunicar aquel mensaje o discurso que deseamos que la gente reciba; en tercer lugar, nos permite establecer formas de capturar la atención de la gente y que ésta sienta curiosidad por acercarse a nuestra institución (Figura 1).

Figura 1

La mercadotecnia aplicada en unidades de información

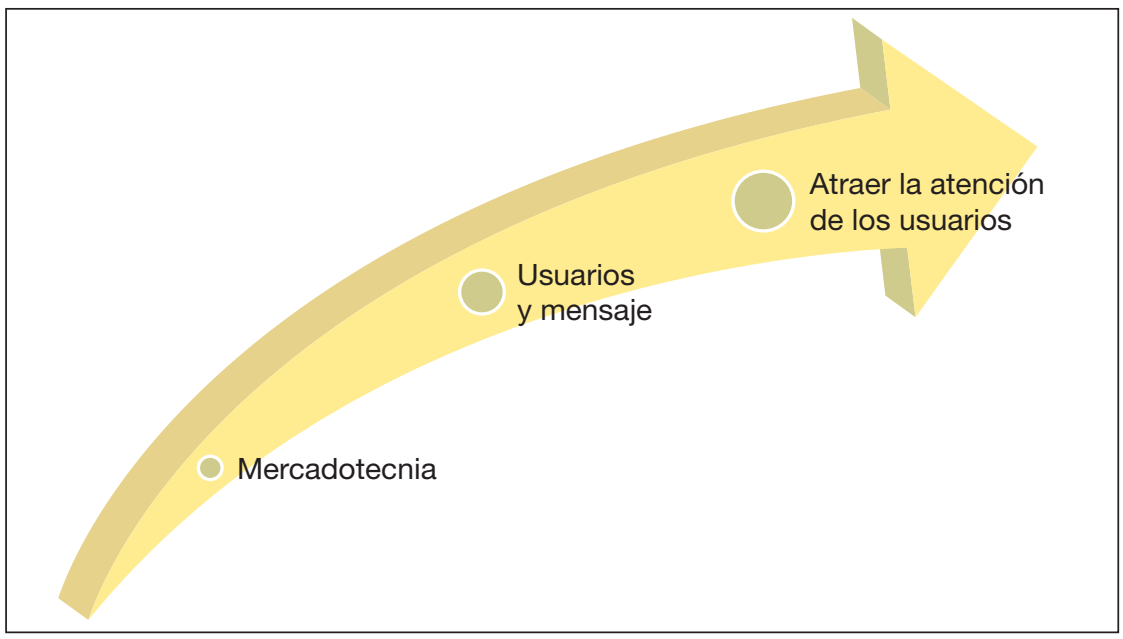

Para llegar a ese público del cual queremos llamar o capturar su atención, es necesario plantear una estratagema que nos permita llegar a tal fin; esta parte de planeación es conocida como estrategia de mercadotecnia; por otra parte, el desarrollo de herramientas que permitan acercarse a la 
voluntad, gustos y atención del usuario se define como tácticas de mercadotecnia (Doucett, 2008).

\section{Estrategia de mercadotecnia}

De forma sucinta, los elementos señalados en la Figura 2 componen una estrategia de mercadotecnia establecida para llegar a esa parte de la población a la que pretendemos ganar su atención y hacer llegar nuestros servicios.

Figura 2

Elementos de la estrategia de mercadotecnia

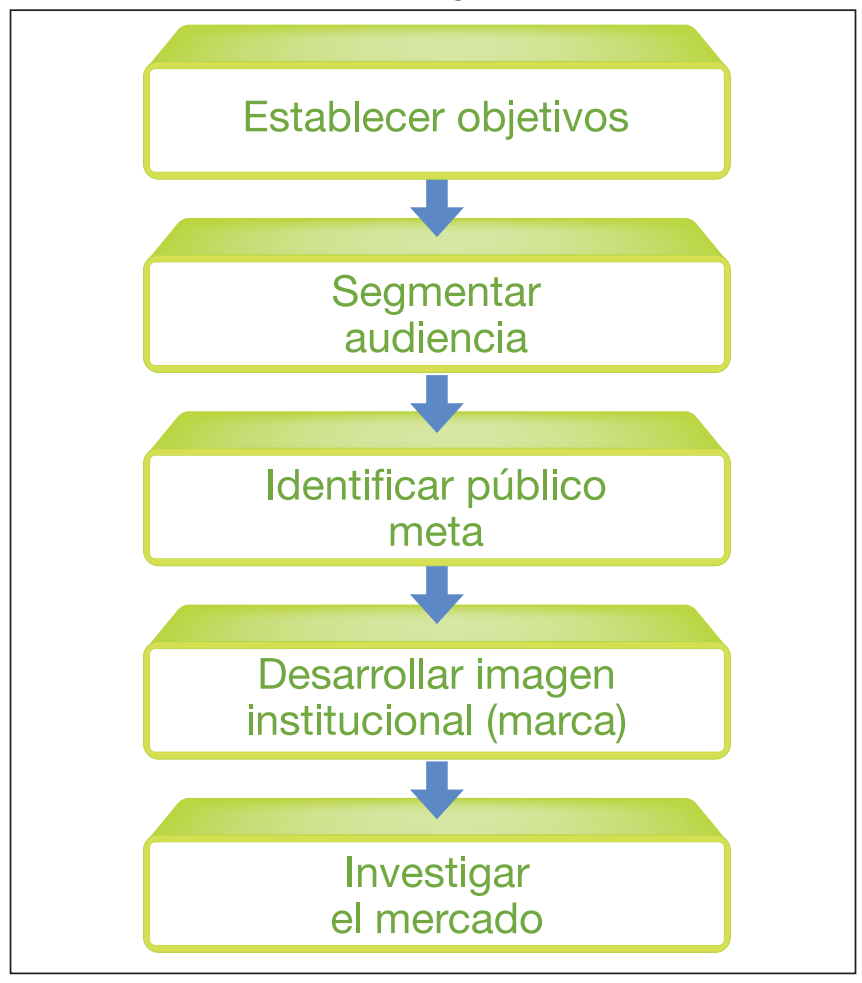




\section{Establecer objetivos}

Como todo proceso planificador, el primer paso en la estrategia de mercadotecnia es, sin duda, la creación de objetivos o metas que dirijan la acción. En el caso de unidades de información, estos objetivos podrían tener que ver con los siguientes intereses:

a) Atraer más usuarios.

b) Consolidar las preferencias del público que ya forma parte de nuestra clientela (usuarios reales).

c) Dar a conocer el capital intelectual que la unidad de información posee.

Es, pues, de capital importancia que la elaboración de estos objetivos sea clara, concisa y cuantificable, en el entendido de que a mayor precisión en el establecimiento de objetivos, menor margen de error en los resultados.

\section{Segmentar audiencia}

Aunque dividir es, generalmente, una acción que merma, en el caso de la mercadotecnia dividir nos permite identificar aquella parte de usuarios a la que pretendemos llegar. Al segmentar, somos capaces de identificar el universo de gente que representa nuestro interés. Esta segmentación se puede hacer vía diferentes características:

a) Demográfica (edad, género, ingresos, lugar de residencia).

b) Intereses o gustos (artistas, deportistas, manualidades, entretenimiento, etcétera). 
Entre mayor definición se logra en las características de aquello que se segmenta, mucho mayor conocimiento de esos grupos o intereses a los que intentamos hacer llegar nuestros servicios (público meta).

\section{Identificar público meta}

Idealmente se espera que una biblioteca llegue e interese a todos; sin embargo, cuando intentamos centrar nuestra atención en cierta parte de los usuarios u ofrecer algún nuevo servicio, es indispensable identificar y conocer ese sector de la población al cual pretendemos dirigirnos y difundir nuestro mensaje. Definir el grupo en el cual estoy interesado garantiza que mis esfuerzos puedan tener eco en el público que representa mi meta u objetivo. Diversas son las preguntas que deberá formular cada unidad de información para identificar a sus usuarios meta y, mientras más se conozca sobre éstos, mayores serán los resultados de nuestra acción.

\section{Desarrollar la imagen institucional (marca)}

Crear un concepto o una historia que le permita al público tener una idea de lo que nuestra institución representa o hace, es parte importante de una buena estrategia. La combinación de lo que la institución representa más la parte iconográfica (logotipo) debe ser tan clara e inteligible que, cuando las personas la perciban, las remita infaliblemente a la esencia de la institución. La comparación puede ser burda, pero debe tener el mismo impacto que tienen las marcas comerciales de hamburguesas, calzado deportivo, o computadoras, cuando el consumidor las percibe. En el caso de unidades de información, la intención sería crear una marca que, una vez percibida por el usuario, lo remita 
a altos estándares en los servicios de información ofrecidos por esa institución.

\section{Investigar el mercado}

Establecer un dialogo entre nuestra institución y sus usuarios -reales o potenciales- permite obtener de primera mano la información indispensable que logre emprender cualquier esfuerzo para el desarrollo de estrategias de mercadotecnia que se pretendan ejecutar. La investigación de mercados incluye no solamente las opiniones que muchas veces vierten los usuarios de forma personal a las personas que laboran en servicios al público (ya sea en el área de consulta o de circulación), sino además algunas otras herramientas que permitan revelar las ideas, posturas, opiniones, etcétera, acerca de la unidad de información y los servicios que ofrece. En este sentido, la aplicación de cuestionarios, entrevistas o muestreos entre algún grupo selecto de usuarios permitirá establecer una estrategia de mercado que tenga impacto en la población a servir.

\section{Tácticas de mercadotecnia}

Aunque probablemente cualquier profesional de la información ha realizado tácticas de mercadotecnia en algún momento de su vida profesional, seguramente este hecho ha pasado rara vez advertido por su conciencia; sin embargo, en opinión de Doucett (Doucett, 2008), los bibliotecólogos están más familiarizados con las tácticas de mercadotecnia que con las estrategias para realizar mercadotecnia. "La difusión, promoción, relaciones públicas, trato directo con las personas, son de hecho tácticas de mercadotecnia" que el 
bibliotecólogo ha realizado y realiza como parte de su labores cotidianas.

\section{Promoción}

Es una actividad dirigida por una institución para dar a conocer o alertar al público sobre un tema o situación específica. La promoción bien puede ser elaborar un folleto o publicar un desplegado en un periódico mural. La promoción lleva la idea de alertar al público acerca de la existencia y los servicios de las unidades de información.

\section{Publicidad}

La publicidad tiene como objetivo dar a conocer un producto con la intención de que las personas encuentren en éste un uso real en su vida. Aunque la publicidad en medios masivos resulta una opción poco viable para unidades de información, con la llegada de la Web 2.0 se abren posibilidades reales y a bajo costo para poder llevar publicidad utilizando Facebook o Twitter, por ejemplo.

\section{Trato directo}

Esta actividad supone establecer comunicación directa con el usuario utilizando principalmente el correo ordinario o el electrónico, o bien, el uso de la red telefónica; sin embargo, con la integración de tecnologías Web 2.0 que permiten establecer comunicación en tiempo real con otra(s) persona(s), la tarea se facilita y se convierte, a la vez, en una posibilidad real para poder interactuar con aquellos quienes representan nuestro público meta. 


\section{Relaciones públicas}

El concepto relaciones públicas sugiere, como la connotación lo indica, el establecimiento de conexiones entre la institución y un público determinado; adicionalmente, convendría agregar que dicha actividad permite comunicarse con veracidad y efectividad con la audiencia de interés (Friesleben, 1995).

Las relaciones públicas aplicadas a bibliotecas y unidades de información deben procurar informar e influenciar a sus públicos. "Los objetivos de las relaciones públicas en una biblioteca pueden ser utilizados para obtener o incrementar financiamiento, mejorar la imagen institucional, incrementar la participación del público, aumentar la credibilidad" (Siess, 2003).

A través de los párrafos anteriores hemos podido constatar que la mercadotecnia no solamente guarda cierta familiaridad con nuestra disciplina, sino que representa, además, una herramienta que puede ser aplicable a los entornos donde el manejo y el comportamiento de la información encuentran su esencia y razón de ser. A continuación revisaremos la forma en cómo las redes sociales están cambiando la manera de hacer mercadotecnia.

MERCADOTECNIA, REDES SOCIALES Y SU APLICACIÓN EN UNIDADES DE INFORMACIÓN

Las opiniones que permean nuestra concepción sobre mercadotecnia y redes sociales pueden ser diversas, pero pretender no valorar sus posibles beneficios podría ser poco redituable. Como los números pueden formar criterios en 
la toma de decisiones, convendría entonces revisar lo que dicen éstos respecto a las redes sociales:

De acuerdo con información de la firma Emarketer (Social Networking, 2013), empresa dedicada a la mercadotecnia digital en 2013, una de cada cuatro personas en el mundo utilizó redes sociales. hacia el 2014 habrá un incremento de usuarios en redes sociales que será de 1.97 billones de usuarios en el mundo.

Facebook es la red social con mayor número de usuarios. Cuenta con 960 millones de suscriptores. Le sigue Twitter, con 170 millones de usuarios; y en tercer lugar, Tumblr, con 120 millones de usuarios, de acuerdo con datos de la firma Find the Best (Compare Social Networking, 2013).

- La actividad más popular a nivel mundial cuando se navega en línea es accesar a redes sociales, de acuerdo con datos de Comscore (It is a Social World, 2012).

- Más de una tercera parte de las personas prestan atención a productos o servicios anunciados en redes sociales que son recomendados por amigos o conocidos, de acuerdo con cifras de Nielsen (State of the Media, 2012).

- Se estima que el 63\% de los usuarios de Internet en México utilizó Facebook por lo menos una vez al mes en 2012 (Winkels, 2013).

- EL 86\% de las bibliotecas públicas en Estados Unidos utiliza los medios sociales para realizar mercadotecnia (Public Library Marketing Survey, 2012).

Las cifras, per se, son concluyentes y abrumadoras. No hay, pues, argumentos que impidan o que logren efectos disuasivos para no considerar a la mercadotecnia y a las redes sociales como instrumentos viables y válidos para su utilización en bibliotecas y otras unidades de información. 
El siguiente paso consistirá en identificar aquellas plataformas Web 2.0 que, por su popularidad, gozan de buena credibilidad entre el público o que han sido ya utilizadas con resultados comprobados. La lista incluye los siguientes sitios Web 2.0.

\section{Youtube}

La plataforma Youtube es la herramienta que ofrece mayores opciones para el gremio bibliotecológico. Es sencilla de utilizar, amigable con el usuario, y ofrece las siguientes posibilidades al profesional de la información:

- Subir videos a Internet y editarlos.

- Realizar campañas publicitarias.

- Promover recursos y servicios.

- Crear canales propios de contenidos.

- Alfabetización Informacional.

- Capacitación de usuarios.

- Realizar estudios de usuarios vía análisis de datos.

- Segmentar mercados.

- Manejo de marca o imagen institucional.

- Crear imagen institucional.

- Compartir contenidos con usuarios.

- Establecer comunicación con usuarios.

- Identificar intereses y preferencias del público.

Para acceder y explotar los recursos que Youtube ofrece, es necesario crear una cuenta con Google a través de cualquiera de sus productos: Gmail, Google plus (Google+), Google Drive, etcétera. 


\section{Facebook}

Facebook es una de las plataformas Web 2.0 más populares en el mundo (es la tercera página más utilizada después de Google y Microsoft). Para el profesional de la información, es de interés por las siguientes características:

- Interacción con los usuarios en tiempo real.

- Herramientas para realizar campañas publicitarias.

- Manejo de marca o imagen institucional.

- Promover recursos y servicios.

- Compartir imagines y videos.

- Segmentar mercados.

- Establecer comunicación con usuarios.

\section{Twitter}

Twitter tiene 288 millones de usuarios activos en promedio por mes. Las oportunidades que ofrece para hacer mercadotecnia en unidades de información no son tan variadas como lo es en las plataformas anteriormente mencionadas. Aun así, su consideración puede ser de utilidad en los siguientes rubros:

- Manejo de marca o imagen institucional.

- Realización de campañas publicitarias.

- Comunicación con usuarios.

- Compartir contenidos.

\section{Blogging (Wordpress, Blogger)}

Escribir una bitácora (blogear, dirán otros en lenguaje coloquial) es una herramienta que, bien utilizada, puede regre- 
sar buenos dividendos a los profesionales de la información. Contar con una bitácora nos permite expresarnos sin la premura del tiempo y tener un público cautivo que, si somos capaces de atraer su atención, se convertirá en un fiel receptor de nuestros mensajes. Wordpress y Blogger son las bitácoras de mayor uso entre los usuarios de plataformas Web 2.0. Su tecnología permite:

- Crear y compartir contendidos.

- Segmentar mercados.

- Promover recursos y servicios.

- Establecer comunicación con usuarios.

Existen otras plataformas Web 2.0 -Wikis, Flickr, Myspace, por mencionar algunas- que también podrían llegar a incluirse sabedores de su potencial, pero de acuerdo con la encuesta realizada por la Biblioteca Estatal del Sur de Carolina (Rogers, 2011) Facebook, Twitter, Youtube y los blogs -bitácoras- son las redes sociales que más se están utilizando en las bibliotecas de los Estados Unidos; adicionalmente, hay que mencionar que, además de estas plataformas, convendría que el profesional de la información se familiarizara con otros sitios Web 2.0 que le pudieran ser de utilidad no solamente para las labores de mercadotecnia, sino también para ampliar y complementar su experiencia cotidiana. Para tener una lista extensa de estos sitios Web 2.0, se puede ingresar al siguiente vinculo: http://go2web20.net/ ya que sería prácticamente imposible destinarles un espacio en este documento, cuya finalidad ha sido diseñada para ser utilizado apenas como un punto de partida en el extensor mar que éstas tecnologías ensanchan.

Imposible, pues, intentar ofrecer una descripción de los pormenores de cada recurso sin caer en la necesidad de 
tratar a cada uno como un ente separado. Nos llevaríamos una gran extensión ilustrando cada plataforma y las minucias que a cada una competen, por lo que exhortamos recurrir a otras obras que, por su orientación, han de servir como un manual de consulta más que como material de inducción; se sugiere también utilizar la documentación que cada plataforma ha colocado a manera de guía o sección de preguntas frecuentes en cada sitio, con la intención de que la información ahí incluida resuelva las inquietudes más comunes e inmediatas.

Sin embargo, y sin la intención de ser una guía definitiva sino de inducción tal y como ya se ha mencionado, el interesado podrá iniciar su aproximación al mundo de la mercadotecnia y su aplicación en bibliotecas utilizando las herramientas Web 2.0 que hemos mencionado líneas atrás; para ello, se ha condensado en el esquema que se muestra en la Figura 3 la información vertida a lo largo de este capítulo, con el propósito de que sirva como un mapa de ruta.

Se deberá tener siempre en mente que la mercadotecnia es una herramienta propicia para conocer y acercarnos a aquel a quien llamamos usuario, y que la utilización de las redes sociales para ese propósito nos coloca en la ruta de que ese usuario se encuentre con nosotros en un trato lineal, de uno a uno y de mayor colaboración entre las partes; como colofón, se ha incluido, además, un glosario de términos que, con toda seguridad, el lector ha encontrado o encontrará en sus tropiezos con la tecnología 2.0

Para cerrar la lectura del presente capítulo a quien esto escribe le gustaría mencionar, a manera de reflexión, que todo nuevo aprendizaje, cambio o acción trae consigo no solamente nuevos retos, sino además "relatividad". Todo es relativo, excepto la intención con la que se realizan los actos; somos testigos de un mundo más conectado, con ex- 
ceso de información, parcialmente comunicado y, hay que decirlo, separado por brechas y capacidades tecnológicas diferentes. La tecnología nos arrastra y sucumbiremos con ella cuando nuevas formas tecnológicas desfasen a las que ahora nos apremian.

No hay forma, por desgracia, de anticiparse al futuro pero sí artificios para convivir con él, y para cuando éste llegue, sería deseable haber fincado ya los cimientos que nos hayan permitido establecer sociedades más justas, prosperas y que empoderen la información y el conocimiento.

No habremos de preocuparnos por el porvenir si comenzamos a trabajar desde ahora concienzudamente con la tecnología que nos permea. Si bien hay aplicaciones Web 2.0 que son superficiales, existen algunas otras que promueven la creación de novedosas formas de cooperación, enseñanza y aprendizaje. Cultivemos, pues, no el hábito de "conectarnos", sino el valor intrínseco de relacionarnos y establecer fuertes vínculos comunitarios. Iniciemos con la tarea de edificar comunas y a desarrollar aldeas locales primero, antes de privilegiar lo global. Vamos planteando nuevas estructuras y formas de colaboración. Vamos creando hábitos que permitan a los individuos revalorar el rol de las bibliotecas, centros y servicios de información en nuestra sociedad. Como mencioné líneas arriba, frente a nosotros aparece una genuina oportunidad de dar un giro determinante al status quo predominante si entendemos cómo utilizar a conveniencia y beneficio la telaraña social y las tecnologías Web 2.0 
Las redes sociales en las unidades de información

Figura 3

Mercadotecnia estratégica

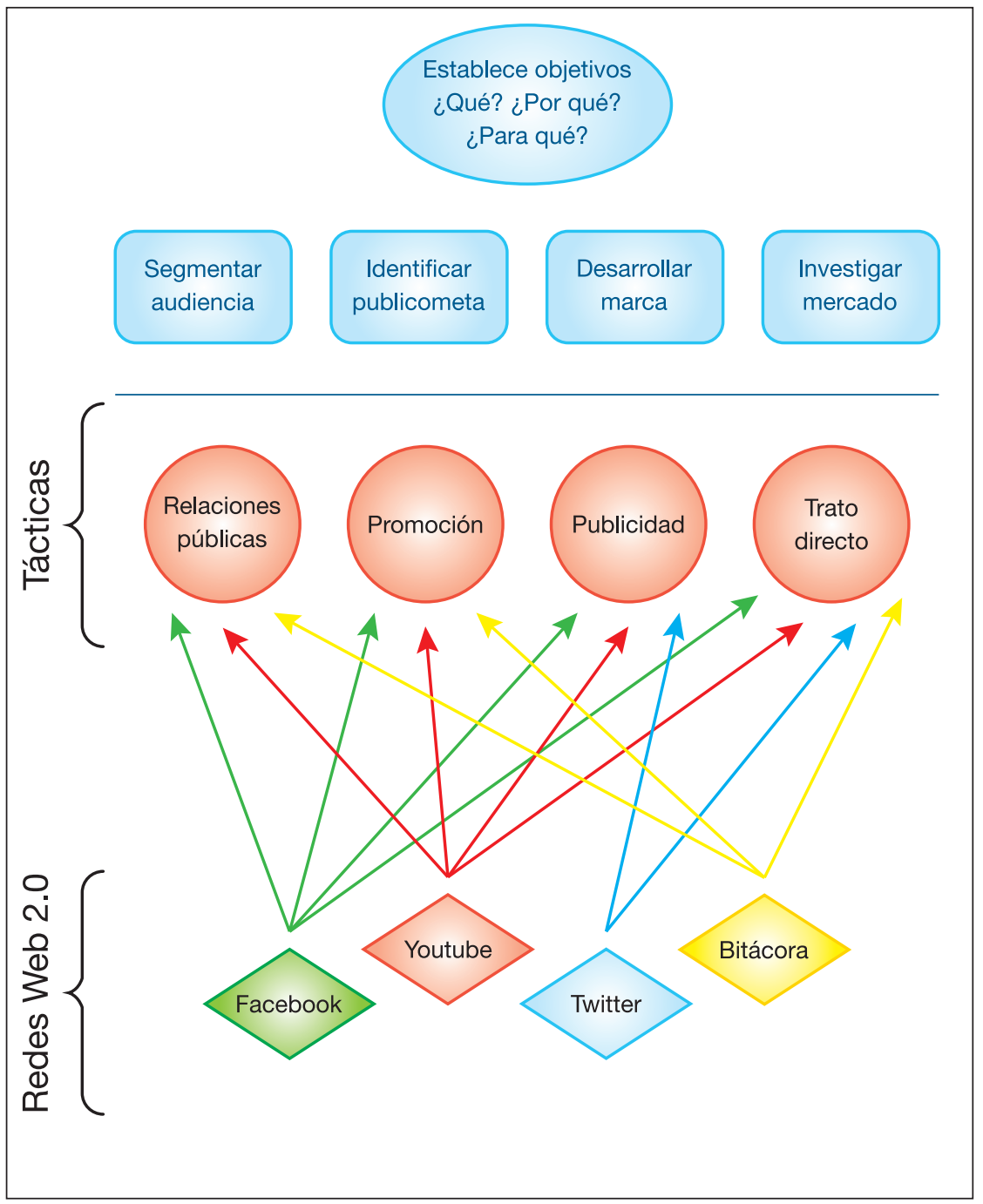




\section{GLOSARIO DE TÉRMINOS FRECUENTES ENCONTRADOS EN LA WEB 2.0 Y BIBLIOTECA 2.0}

AdSense: programa de publicidad gestionado por Google dirigido a administradores de páginas Web. Sirve para añadir publicidad a un blog o a cualquier página Web.

AdWords: programa de publicidad patrocinado por Google orientado a todo aquel que pretenda anunciar sus productos o servicios en Internet. Sirve para anunciarse en páginas Web cuyo tema está relacionado con el producto que se intenta hacer publicidad.

Agregador (Aggregator): programa que permite tomar o recoger contenidos de diversas fuentes Rss y mostrarlos en una misma página Web.

Avatar (personaje virtual): carácter imaginario el cual intenta hacer una réplica de una persona real, pero utilizada en ambientes irreales.

Banner: puede ser una imagen, un gráfico o un texto utilizado con fines publicitarios que aparece en una página Web; habitualmente este anuncio dirige al sitio Web del anunciante.

Biblioteca 2.0: el término sugiere una nueva generación de servicios y recursos ofrecidos por las unidades de información, los cuales son desarrollados utilizando la Web 2.0. Están basados, principalmente, en una mayor colaboración y participación de los usuarios.

Blog: un blog o weblog -bitácora en español- es un sitio Web periódicamente actualizado que recopila en forma cronológica, textos o artículos escritos en forma personal o colectiva.

Blogger: persona que escribe en una bitácora.

CMS (Content Management System): sistema de gestión de contenidos que permite la creación y administración de información en una página Web. 
Del.icio.us: servicio en línea que permite gestionar y compartir información de diversa índole, como sitios Web, noticias, etcétera, los cuales son considerados como favoritos por el usuario. Esto le permite que dicha información esté disponible desde cualquier medio conectado a Internet.

Emoticons: combinación de símbolos que permiten simular la apariencia de diversos gestos del rostro humano, comúnmente utilizados en los textos para expresar emociones en los mensajes entre usuarios.

Etiqueta (tag): una etiqueta es una palabra clave o término asociado con un material informativo (como una fotografía, un artículo, un sitio Web o un video clip) que describe el material. Un elemento puede tener más de una etiqueta asociada.

Ezine: revista electrónica publicada en una Web o distribuida por correo electrónico.

Faceboook: red social cuyo objetivo es poner en contacto -originalmente- amigos y familiares con los que es posible compartir fotografías y todo tipo de archivos.

Folksonomy: sistema de clasificación que categoriza, mediante el uso de etiquetas, la información que en la práctica cotidiana ha sido compartida en forma colaborativa. La idea de esta clasificación es que permita encontrar información de una manera más rápida y sencilla.

Foros: aplicaciones de Internet que dan soporte a discusiones en línea.

LinkedIn: red social enfocada a profesionales de diversas áreas; útil para encontrar especialistas y oportunidades de empleo.

Marcadores sociales (social bookmarking): servicio basado en la Web que sirve para compartir sitios favoritos con otras personas en Internet. 
Marketing viral: estrategia de mercadotecnia realizada en Internet que induce al público a retransmitir un mensaje hasta volverlo exponencialmente contagioso.

Mash-up: aplicación o página Web que utiliza contenido informativo de más de una fuente de información. Podría ser definido como una mezcla de recursos que puede permitir crear nuevos contenidos.

Meme: idea, comportamiento o estilo que se difunde de persona a persona, hasta permear en la sociedad.

Podcast: transmisión digital realizada a través de Internet que generalmente se difunde en forma seriada y que puede ser copiada a dispositivos electrónicos (computadoras, teléfonos celulares).

Redes sociales: plataformas que permiten a las personas comunicarse y colaborar en tiempo real. Estas redes pueden crear comunidades en línea que, bien utilizadas, pueden ser dirigidas a la resolución de metas o problemas comunes.

RSS: siglas de Really Simple Syndication, un formato de texto estandarizado que distribuye titulares de noticias y contenidos de forma automatizada, cuyo objetivo es mostrar un sumario o índice de los contenidos sin necesidad de ingresar a la página Web origen.

Software social: herramientas que sirven para crear y mantener sitios comunitarios. El ejemplo más notable es Wikipedia.

Technorati: herramienta de búsqueda que permite localizar blogs y weblogs.

Twitter: sitio Web de microblogging donde se colocan mensajes de hasta 140 caracteres.

Videoblogging: una bitácora -blog-, pero transmitida en formato audiovisual. 
Webcast: difusión de emisiones de audio y video en directo por Internet. Los webcast usan tecnología streaming media (de difusión continua), para realizar las presentaciones en la red de redes.

Widget: pequeños programas que muestran en una ventana de la computadora los contenidos de Internet seleccionados por el usuario, como servicios generales o weblogs.

Wiki: sitio Web que permite a los visitantes colaboradores añadir, eliminar y cambiar sus contenidos. Permite asimismo realizar enlaces entre todas las páginas que se desee. Esta facilidad de interacción y manejo hace de un wiki una herramienta eficaz para la creación cooperativa de masas. El término también se aplica a los propios programas informáticos cooperativos (herramientas wiki) que facilitan el manejo de estos sitios o a determinados sitios wiki, como las enciclopedias del tipo Wikipedia.

WordPress: uno de los programas de mayor aceptación para editar y crear weblogs de licencia libre.

Web 1.0: se refiere al concepto original de la Web que comenzó con el desarrollo de páginas estáticas HTML que no eran actualizadas frecuentemente. En esta etapa de desarrollo conseguir hits (visitas) y la estética visual eran considerados como uno de los factores más importantes de desarrollo de cualquier sitio Web.

Web 2.0: se usa para referirse a una segunda generación de Web basada en comunidades de usuarios y una gama especial de servicios, como las redes sociales, los blogs, los wikis, que fomentan la colaboración y el intercambio ágil de información entre los usuarios. En la Web 2.0, se busca un intercambio de información en dos sentidos, y el usuario deja de tener un rol pasivo y pasa a ser parte de la generación de la información.

Youtube: sitio web que permite subir, editar y compartir videos para una audiencia muy diversa. 


\section{BIBLIOGRAFÍA}

Clemmitt, M. (2008), "Reading crisis?", en CQ Researcher, núm. 18, pp. 169-192 [en línea], http://library.cqpress.com.vlib.interchange.at/cqresearcher/

Compare Social Networking. Find the Best. 2013 [en línea], http:// social-networking.findthebest.com/

Doucett, Elizabeth (2008), Creating your Library Brand: Communicating your Relevance and Value to your Patrons, Chicago, ALA.

Ezeani, Chinwe Nwogo (2012), "Using Social Media for Dynamic Library Service Delivery: The Nigeria Experience", en Library Philosophy and Practice, p. 3

Friesleben Goff, Christine (1995), El proceso de las relaciones públicas, México, Publigrafics.

Gunelius, Susan (2011), 30-Minute Social Media Marketing, New York, Mc Graw Hill.

It is a Social World: Top 10 Need-to-Knows About Social Networking and Where It's Headed [en línea], http://www.comscore. com/Insights/Presentations_and_Whitepapers/2011/it_is_a_ social_world_top_10_need-to-knows_about_social_networking

Kevin Curran, Michelle Murray et al. (2006), "Involving the User through Library 2.0" en New Review of Information Networking, vol. 12, núm. 12, pp. 47-59.

Losowsky, Andrew, “The Huffington Post. Why It's Time to Speak Up For Our Libraries" [en línea], http://www.huffingtonpost.com/ andrew-losowsky/libraries-in-crisis-introduction_b_1096030. html

Merriam Webster. Dictionary Online. Definition of Social Media [en línea], http://www.merriam-webster.com/dictionary/social\%20media 
McLuhan, Marshall (1996), Comprender los medios de comunicación, las extensiones del ser humano, Barcelona, Paidos.

O`Reilly, Tim (2005), "What Is Web 2.0: Design Patterns and Business Models for the Next Generation of Software" [en línea], http://oreilly.com/web2/archive/what-is-web-20.html

Rogers, Curtis R., (2012), Social Media, Libraries, and Web 2.0: How American Libraries are Using New Tools for Public Relations and to Attract New Users - Fourth Annual Survey [en línea], http://www.statelibrary.sc.gov/docs/pr/201202_com_social_media_survey_dec_2011.pdf

State of the Media: the Social Media Report 2012 [en línea], http:// www.nielsen.com/us/en/reports/2012/state-of-the-media-thesocial-media-report-2012.html

"Social Networking Reaches Nearly One in Four Around the World" [en línea], http://www.emarketer.com/Article/SocialNetworking-Reaches-Nearly-One-Four-Around-World/1009976 \#DikHWbKUQkitbKmH.99

Siess, Judith A. (2003), The Visible Librarian: Asserting you Value with Marketing and Advocacy, Chicago, ALA.

Pérez Romero, Luis Alfonso (2004), Marketing social. Teoría y práctica, México, Pearson Educación.

Winkels, Mitchel. "The Global Social Network Landscape: a Country-by-Country Guide to Social Network Usage" [en línea], http://www.optimediaintelligence.es/noticias_archivos/719_20130715123913.pdf 
Mercadotecnia estratégica: teoría e impacto en las unidades de información. La edición consta de 50 ejemplares. Coordinación editorial, Carlos Ceballos Sosa; revisión y evaluación editorial, Aurea Gabriela Mondra 7 gón Pérez; revisión especializada, formación editorial y revisión de pruebas, Servicios Profesionales de Asesoría Financiera y Administrativa. Instituto de Investigaciones Bibliotecológicas y de la Información/UNAM. Fue impreso en papel cultural de 90 g. en Arte Gráfico y Sonoro, Retorno de Amores No. 14-102, Col. Del Valle, México, D. F. Se terminó de imprimir en el mes de septiembre de 2014. 